\title{
The Library of Rudolf Steiner: The Books in English
}

\author{
John Paull \\ School of Technology, Environments and Design, University of Tasmania, Hobart, Australia \\ j.paull@utas.edu.au, john.paull@mail.com
}

\begin{abstract}
The New Age philosopher, Rudolf Steiner (1861-1925), was the most prolific and arguably the most influential philosopher of his era. He assembled a substantial library, of approximately 9,000 items, which has been preserved intact since his death. Most of Rudolf Steiner's books are in German, his native language however there are books in other languages, including English, French, Italian, Swedish, Sanskrit and Latin. His library hosts more books in English than in any other foreign language. Steiner esteemed English as "a universal world language". The present paper identifies 327 books in English in Rudolf Steiner's personal library. Fifty percent of the English-language books identified are categorized as Theosophy $(n=164)$. Rudolf Steiner was the General Secretary of the German branch of the Theosophy Society from 1902, and he hived off his own Anthroposophy Society in 1912. The present study reveals that Steiner maintained his interest in theosophy throughout his life as he stayed up to date with the proliferating portfolio of Theosophy publications. The publication dates of Steiner's Theosophy collection range from 1877 to 1923. The leading exponents of Theosophy in his day are well represented in Steiner's collection, including Annie Besant $(n=61)$, Charles Lead beater $(n=13)$, William Westcott $(n=13)$ and Helena Blavatsky $(n=10)$. Of the other $50 \%$ of the Anglo-books identified, $20 \%$ are in the category of Religion $(n=67), 10 \%$ are Social Science $(n=33), 6 \%$ are Philosophy $(\mathrm{n}=21), 4 \%$ are Science $(\mathrm{n}=13)$, and $3 \%$ each are Anthroposophy $(\mathrm{n}=11)$, History $(\mathrm{n}=9)$ and Arts ( $n=9)$. The publication dates of Steiner's Anglo-books span the period 1659 to 1925. This demonstrates that Steiner was acquiring Anglo-books right to the end of his life. Steiner's library throws light on the development of the thoughts of this remarkable individual and the present paper reveals Steiner's engagement throughout his life with the world of Anglo-publishing and thought.
\end{abstract}

Keywords: Anthroposophy, Theosophy, Society, Dornach, Switzerland, personal library.

\section{Introduction}

Rudolf Steiner (1861-1925) was a New Age philosopher, mystic and polymath who has left an enduring legacy of alternative practices in a variety of domains. The most notable and visible elements of that legacy are biodynamic farming (and thence organic agriculture), Waldorf education (there are over one thousand schools worldwide), organic architecture (the most remarkable example is the present Goetheanum building at Dornach, Switzerland), and the Anthroposophy Society (the entity charged with promulgating Steiner's 'spiritual science' and philosophy and headquartered at Dornach). By all accounts, Steiner was a voracious reader all of his life. As a young man, Steiner edited the scientific works of Goethe, Germany's most esteemed philosopher (Wachsmuth, 1989). In the course of his life, Steiner accumulated a substantial library which, during the latter years of his life, was housed in his home, Haus Hansi, in Dornach, Switzerland, where he lived from 1914 onwards (Paull, 2018a). More than nine decades after his death, that library remains intact in Dornach and is rehoused in the Rudolf Steiner Archive (Figure 1).

Rudolf Steiner always spoke to his English-speaking audiences in German. He requested, as he did at Oxford, "forgiveness that I cannot speak to you in the language of this country. Any disadvantage this involves will be made good, I trust, in the translation to follow" (Steiner, 1922, p.7). When the Italian/Australian artist Ernesto Genoni first met Steiner (in 1920) he received a warm welcome but they did not find a common language: "Unfortunately he was speaking in German which I did not know, but by his long handshake and smiling expression of his face I could feel his sincere welcome" (E. Genoni, c.1970, p.7). Genoni relates that in 1924: "on this second visit [to Dornach, Switzerland] I could speak to DR Steiner in the French language. On the first visit I was unaware that DR Steiner could speak [French]" (E. Genoni, c.1970, p.8). Nevertheless, Rudolf Steiner's personal library reveals a trove of books in English that he acquired over a lifetime, despite not publicly speaking the language.

The library of Rudolf Steiner has survived due to the 'lucky' confluence of several factors including: (a) Steiner was revered in his lifetime; (b) during Steiner's lifetime there were already processes in place to 
preserve material aspects of his life, including, for example, recording the texts of his lectures in shorthand, and retaining his 'blackboard' drawings from his lectures by having him draw on black card; (c) Steiner established the headquarters of the Anthroposophy Society at Dornach, and at the time of his death there was already substantial built infrastructure and governance in place, as well as a coterie of devotees and acolytes in situ; (d) Dornach is just inside the boundary of Switzerland, certainly within earshot of the shelling of war, but the neutrality of Switzerland was respected by the belligerents during both World Wars, and the country did not suffer the destruction that engulfed its neighbors; and (e) Steiner's library was housed at Dornach (for the final decade of his life) and his widow, Marie Steiner, as the keeper of the books, was keen to preserve and progress the legacy of her husband. The net result is that Steiner's library of about 9,000 items has been safely preserved at Dornach.

Steiner's language was German. He used that language to variously enchant, enthrall, mesmerize and bewilder audiences. He travelled and lectured throughout continental Europe. He always lectured in German. He made ten visits to Britain (Villeneuve, 2004), and there, as elsewhere, his lectures were in German. He did not visit any other English-speaking countries; the furthest west he travelled was Tintagel, on the west coast of Wales (Paull, 2012). The challenge of translating his lectures into English was solved by recourse to the remarkable linguist George Kaufmann (later in life known as George Adams) (1894-1963). To an Anglo audience, Steiner would deliver his lecture in three brackets of twenty minutes each. Following each bracket of German, George Kaufmann would deliver a rendition of comparable length, in English.

Figure 1: The personal library of Rudolf Steiner is re-housed at the Rudolf Steiner Archive, Dornach, Switzerland.

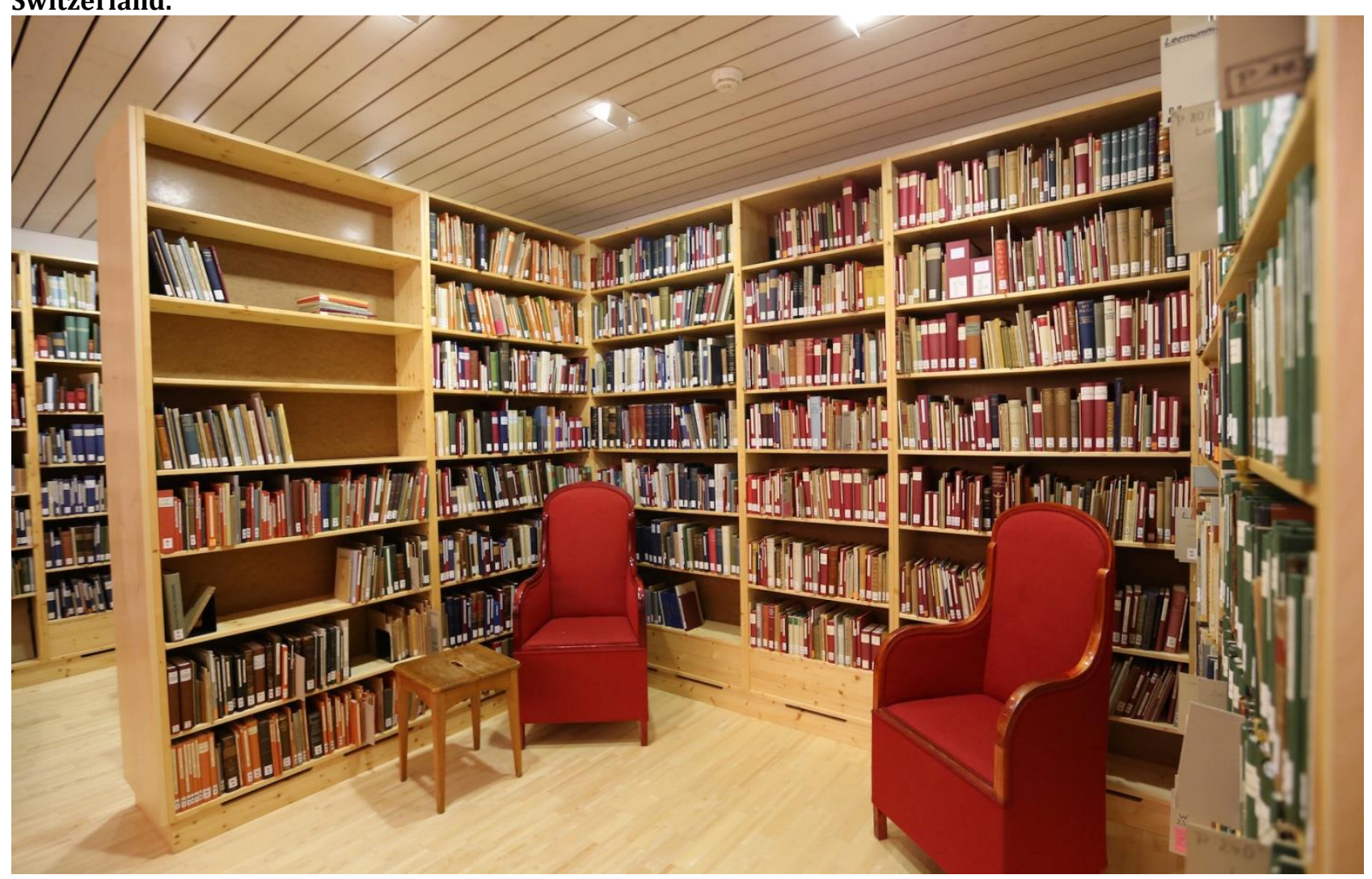

A contemporary account reporting on Steiner speaking at Oxford, relates that: "When he spoke it was clear that he possessed the qualities of expositor and preacher to a matchless degree. Also, being an artist to his fingertips, it was obvious why he spoke in his own tongue, of which he has an absolute mastery ... a large part of an English audience is unable to understand German ... Ordinarily, it would be something of a strain on an audience to listen to three addresses and three translations covering a period of two and a half hours, but ... DR Steiner ... soon holds his listeners under the spell of his power... DR Steiner does not shrink from that 
thoroughgoing formality which gives to his address ... absolute clarity ... Words, phrases, and formulae ... and rhythmical cascades of eloquence ... sometimes reach the rapidity and force of a torrent" (Hare, 1922, p.219221). English was important to Rudolf Steiner. When the first Waldorf School was established in Stuttgart, Germany, in 1919, Steiner was insistent that students learn two foreign languages, one of which was to be English.

He stated that: "English is taught because it is a universal world language, and will become so more and more" (Steiner, 1924c, p.139). Steiner was keen that his messages were delivered to Anglo-audiences. Even in the final year of his public life, when he was suffering from serious ill health, Steiner made the journey to the International Summer School of the Anthroposophical Society held over twelve days in August of 1924 at Torquay, a beach-side town on the south coast of England, where he delivered lectures morning, afternoon, and evening (Paull, 2018b). Others of Steiner's entourage from Dornach, including DR Elisabeth Vreede and DR Guenther Wachsmuth lectured in English at Torquay (Lindenberg, 2017), but for Steiner it was always German. Rudolf Steiner was a bibliophile. Albert Steffen remembered: "Up to the last day of his life, his interest was for the entire world. In his studio, which he had not left for half a year, he had collected an entire library" (1925, quoted in Lindenberg, 2017, p.757). To the very end, Steiner maintained a keen interest in knowledge and ideas and in books as a vehicle for conveying them. In the final months of his life Steiner was bed-bound, yet his appetite for books remained voracious. Gunther Wachsmuth relates his personal testimony that: "from his sick bed, Rudolf Steiner continued as always to do an enormous amount of reading, keeping himself abreast continuously of new publications in science, art, history and all other fields of work.

Since he could no longer visit the bookshops and the dealers in antiquarian rarities, I was given the difficult job of regularly selecting and buying books which might be of interest to him ... Every few days ... I visited the bookshops in Basle, and often in other towns, looking for books which might be what he would care to read. And then, whenever I came to his bedside with a great pile of books ... he thoughtfully took one book after another, looked at the title and the name of the author, turned a few pages, and made his choice. The books that he wished to keep and read he stacked on the right side of the bed, and the others in the left ... How he managed to study the huge pile of books lying on the right side of the bed, in the midst of all his other work, and in spite of his illness, was a mystery, but chance remarks on the next occasion when I brought him books showed that in the meanwhile he had made himself thoroughly acquainted with the contents of their predecessors" (1958, p.167). Steiner wrote, on 5 March 1925, that: "My condition is improving only gradually. And it is imperative that I shall soon be capable of working" (quoted by Wachsmuth, 1989, p.583). On 23 March 1925, he wrote "Everything is progressing terribly slowly with me. I am really quite desperate about the slowness" (in von Arnim \& von Arnim, 1988, p.263). Rudolf Steiner died on 30 March 1925 (Collison, 1925).

Personal libraries are typically dispersed after the owner's demise. For example, the personal libraries of the authors Lewis Carroll and Richard Adams were sent to auction (Flood, 2017, Stern, 1981). In one way or another, most personal libraries are disaggregated and dispersed. For example, in the present author's library are the Agriculture Course issued to Ileen Macpherson (Copy No. E.52, Steiner 1924a) and the German version of the same book, Land Wirtschaftlicher Kursus, issued to Baron DR von Veltheim-Ostrau (Copy No. 257, Steiner 1924b). Rather than being disaggregated, some personal libraries have been aggregated into larger collections, for example, Catherine the Great of Russia acquired the personal libraries of others and incorporated them into her own library (Miles, 2018). Other personal libraries have suffered the vagaries of history. Personal and public libraries throughout Europe were lost to incendiary bombing and fire during World War 2. In Russia, during the Siege of Leningrad (1941-1944), many treasured books were dispatched to the oven in a desperate bid to survive sub-zero winters (Peri, 2017). During the Cultural Revolution (19661976) in China, in a paroxysm of revolutionary ardor, Red Guards of Mao Zedong (1893-1976) destroyed many foreign and antiquarian books (Robinson, 1970). Rudolf Steiner's personal library has survived intact. The present paper identifies the English-language books of that library.

\section{Methodology}

Rudolf Steiner's personal library is preserved, shelved in a basement of the Rudolf Steiner Archive at Dornach Switzerland. The present account relies on the books of the library, a card file system of the books of the 
library, and a print out of some of the books of the library. The library items are not shelved by language. For the present account, the English-language items have been selected out.

\section{Results}

The personal library of Rudolf Steiner is a library reportedly of about 9000 items according to the Rudolf Steiner Archive of Dornach. In the present study, 327 items are identified as English language publications. These items are presented in Appendix A. In that appendix, the Anglo items are referenced in APA style, in alphabetical order by author, and numbered. Where an author has several items in Appendix A, those items appear in chronological order. In each case, items in Appendix A bear the Rudolf Steiner Archive Number (RSA\#) and a book category. In general, the category specified in Appendix A follows that of the Archive, with a handful of exceptions were the category specified in Appendix A is that which seems arguably more appropriate to the present author. It needs to be borne in mind, that single-category typologies suffer the defect and the contestability of the subjectivity of selecting the most appropriate category from what may be a competing list (for example, consider a hypothetical title, The History and Philosophy of Hindu Arts and Sciences, which could arguably be classified as History, Philosophy, Religion, Arts or Science). That is expected and understandable given that German was Rudolf Steiner's first language. He was a master of this language and none other. Steiner travelled widely and frequently within Europe (but not beyond), his public presentations were in German, and for non-German speaking audiences he relied on a translator. Section 3.1 identifies, in passing, some data and books of Rudolf Steiner's library of incidental or contextual interest to the present paper. Section 3.2 and Appendix A together constitute the substantive content of the present paper, and they describe and list the 327 Anglo-books identified in Rudolf Steiner's library.

\section{The Non-Anglo Books}

Books in Other Languages (neither German nor English): Besides the books in German (the bulk of the library) and English (Appendix A), there are other books in their original languages in Steiner's personal library. For example, there are books in Italian (e.g. Caniglia, 1922; Colombo, 1921; R. Genoni, 1924), in Dutch (e.g. Vissering, 1920), in Swedish (Hellberg, 1922), in French (e.g. Cheftele, 1920; Maday, 1913; Piaget, 1915) and in Latin (e.g. Fludd, 1687).

Books in German Translated from Other Languages (including from English): In general, it appears that, where a German translation was available of a book, then that translation was preferred by Steiner. In his library we find, many foreign authors translated into German. German translations of English-language books in Steiner's personal library, include, for example, books by the American industrialist Henry Ford (RSA\# G 0241), by US politician Theodore Roosevelt (RSA\# G 0734), by British art critic John Ruskin (1819-1900) (RSA\# G 0766), and by British historian and politician Thomas Macaulay (1800-1859) (RSA\# G 0551). There are German translations of non-English-language books, for example, by, Russian revolutionary leaders Vladimir Lenin (1870-1924) (RSA\# G 0523) and Leon Trotsky (e.g. RSA\# G 0898), and by Russian author Leo Tostoy (e.g. RSA\# G 0897).

Books in German about England and Anglo-Authors: Steiner's library reveals his keen interest in England and the English. Titles in his personal library include: Der English Charakter (Fontane, 1915, RSA \# G 0240), English Denkträgheit (Schultze, 1915, RSA\# G 0808), Das Modern England (Keller, 1915, RSA\# W 159), and Gegen England (Wagner, 1914, RSA\# W 323). Books about Anglo-authors include books about Charles Darwin (by Peryer, 1896, RSA\# N 440), about William Shakespeare (by Tolstoi, 1906, RSA\# L 261), and about US author Walt Whitman (by Schlaf, 1897, RSA\# L 221).

The Books in English (n=327): There are 327 books in English identified. These books are listed in Appendix A. The publication dates of Steiner's English books range from 1659 to 1925 (Fig. 2). There is a date anomaly with one item dated 1926 (Fig. 2). There is a peak at 1904, and subsidiary peaks at 1896, 1900, 1920 and 1922. What is clear is that Steiner was active right to the end of his life in building his library. Fifty per cent of the English-language books is Theosophy titles $(n=164)$ (Fig. 3). They range in date from 1877 to 1923 (Fig. 4). The four leading Theosophy authors Annie Besant ( $n=61)$, Lead beater $(n=13)$, Westcott $N=13)$ and Blavatsky $(\mathrm{n}=10)$ account for $59 \%(\mathrm{n}=97)$ of the Theosophy books of Steiner's library (Fig. 5). 
Presentation Copies (n=19): Of the 327 Anglo-books identified, 19 are inscribed presentation copies (6\% of the Anglo-books). The various authors reflect Steiner's circle of acquaintances and interests. The remaining 308 Anglo-books can be taken to reflect Steiner's personal acquisitions. Nineteen of the Anglo-books are identified as inscribed to Rudolf Steiner. Of these, most are inscribed by the author $(n=14)$, while the remainder are inscribed by the editor $(n=5)$. Inscribed copies are noted as such in Appendix A. The five books inscribed by the editor are all works by Steiner himself and translated into English (see Appendix A: \#s 277, $278,279,283,285)$. The works inscribed by the author include works on Anthroposophy (Appendix A: \#170), the Arts (\#8), History (\#96), Philosophy (\#s 205, 206, 207, 208, 209), Religion (\#s 123, 227, 304), Science (\#s 178, 290) and Social Sciences (\#250).

Figure 2: The Publication Dates of Anglo-Books in the Personal Library of Rudolf Steiner.

25

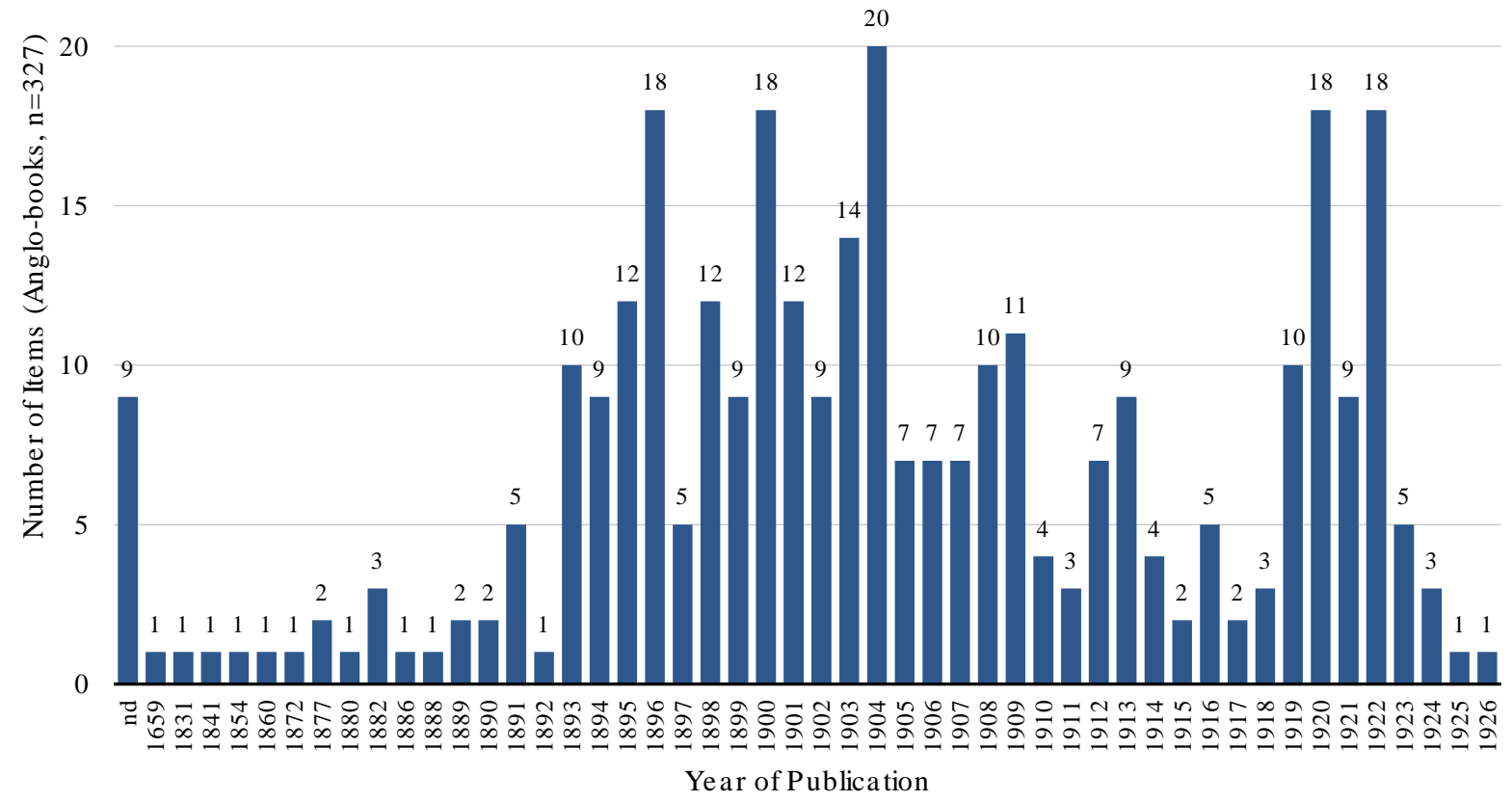

Timeline: The timeline of the publication dates of Steiner's Anglo-books stretches from 1659 and reveals a bimodal distribution (Fig. 2). There is a tail stretching back to 1831 (Appendix A \#148, a history of England) with an outlier dated 1659, an obscure title exhibiting the spelling of a bygone era, Mosaic all Philosophy: Grounded upon the Essential Truth and Eternal Sapience (sic) (\#140). The two decades from 1893 to 1913 account for 65\% of Steiner's Anglo-library (n= 213), with local peaks in this interval at $1896(n=18), 1900$ $(\mathrm{n}=18)$ and $1904(\mathrm{n}=20)$. This period includes Steiner's peak involvement with Theosophy. There is a trough during the Great War (World War 1; 1914-1918) a time when there were no trips to Britain by Steiner, the publishing output of Britain (and other of the belligerent countries) was constrained by war-time shortages and the appropriation of resources for military purposes, and the interchange of Anglo-books into Germany was truncated by diminished trade opportunities. Steiner was based in Dornach, Switzerland by the time war broke out, but he continued to travel throughout Germany. The early Anthroposophy-style buildings were built in this period, such as the first Goetheanum and the Glass House at Dornach. 
Figure 3: The distribution by category of Anglo-books in the personal library of Rudolf Steiner $(n=327)$.

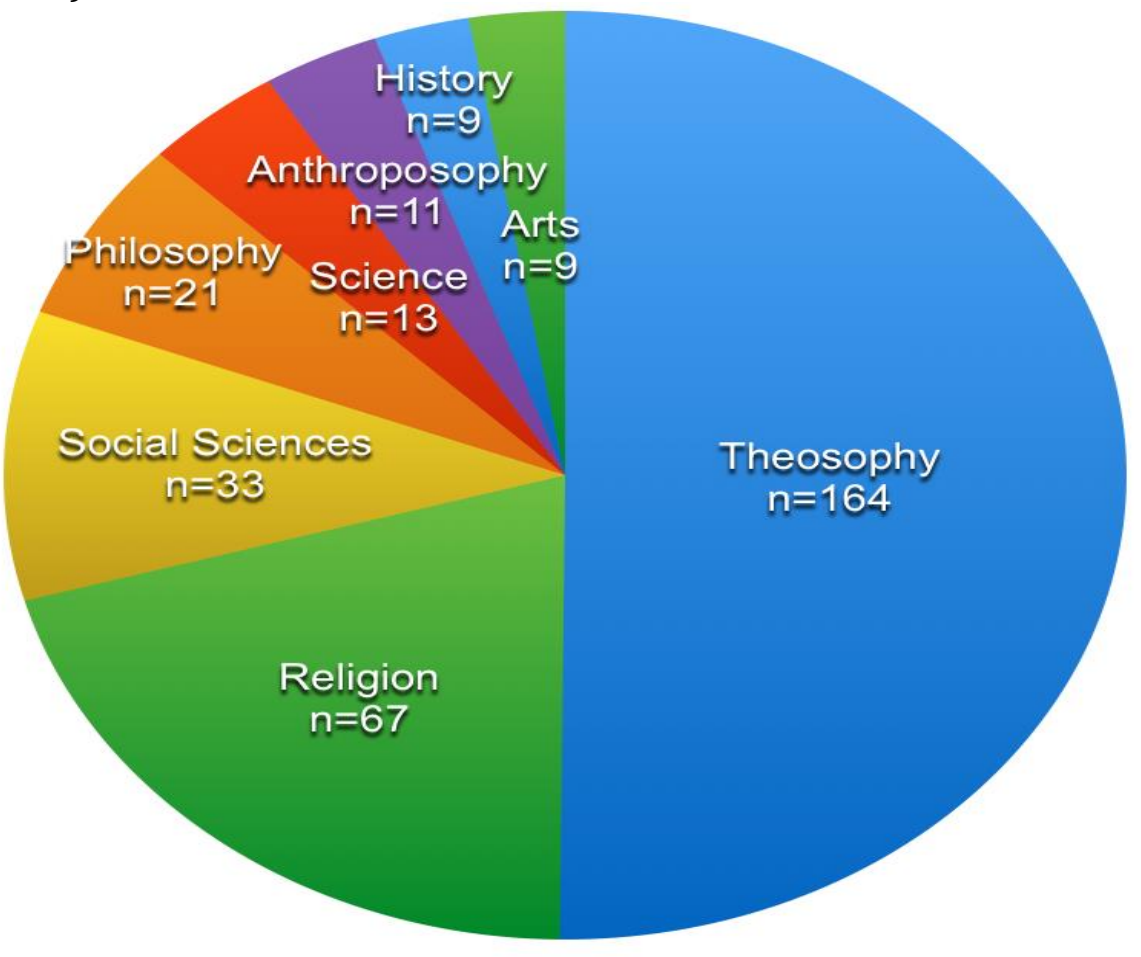

After the Great War (WW1), Anglo-book acquisitions for Steiner's library peak for the publication years of $1920(\mathrm{n}=18)$ and $1922(\mathrm{n}=18)$, and then trail off to just 5 acquisitions for 1923 (the year following the Goetheanum burning to the ground), to 3 in 1924 (\#94 about Ancient Egypt, \#210 a presentation copy on contemporary philosophy, \#303 a Victoria \& Albert Museum catalogue) (it was the year following the claimed poisoning of Steiner), and down to just one for 1925 (\#95, about Ancient Egypt) (the final year of his life). There is a 1926 imprint book by Bhagawan Das (\#123). The date is an anomaly given Steiner's death in 1925; this is either a posthumous addition or a transcription error. The book is a presentation copy from the author based in India with a publisher in Calcutta. This book is not listed in wordcat.org which indicates it is a very obscure title. News of Rudolf Steiner's death in 1925 was reported as far away as in the Australian press (and so most probably in the Indian press) but may have not reached Das. There are presentation copies of books by Millicent Mackenzie (1863-1942) and John Stuart Mackenzie (1860-1935) (see Appendix A) who had both spent time at Dornach, promoted Steiner's ideas on education, and Millicent was an organizer of Steiner's Oxford Conference of 1922 (Paull, 2011). There appear to be no books by L P Jacks (1860-1955), the principal of Manchester College, Oxford where Steiner conducted his first major British Anthroposophy conference following WW1 (Paull, 2010). Jacks made his college available for the Oxford Conference, had a lively interest in education, and he was a prolific author (he wrote at least 19 books) although his books rarely managed a second print run and have not stood the test of time well. There appear to be no Anglo Theosophy books inscribed by the leading Theosophy authors (viz. Besant, Lead beater, Westcott or Blavatsky). 
Figure 4: The Publication Dates of Anglo-Books on Theosophy $(\mathrm{N}=164)$ in the Personal Library of Rudolf Steiner.

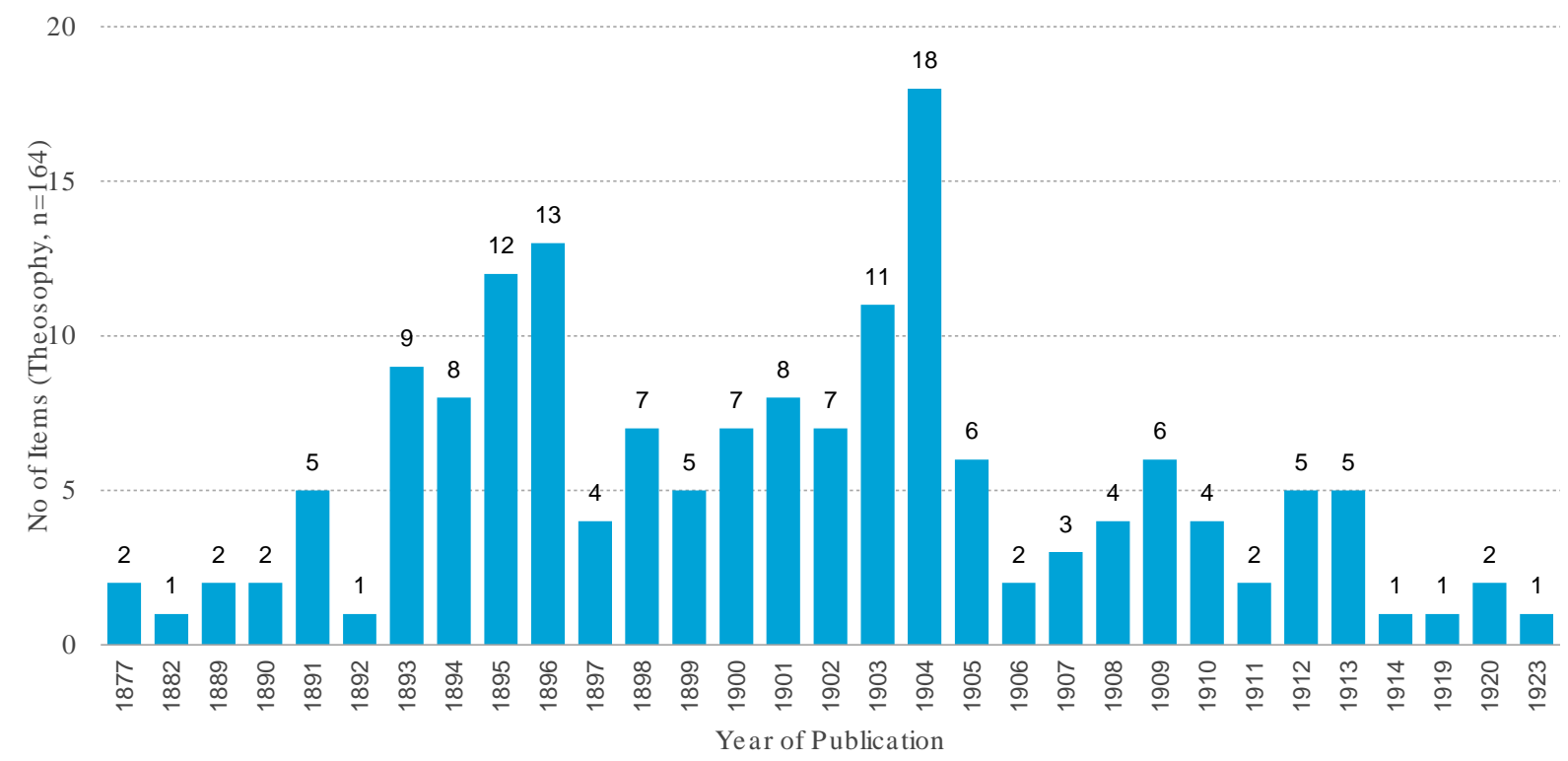

Theosophy $(\mathbf{n}=\mathbf{1 6 4})$ : Theosophy books dominate the Anglo-books of Rudolf Steiner's personal library (Figure 3). The publication dates range from 1877 to 1923 (Figure 4). Steiner was the General Secretary of the German branch of the Theosophical Society from its founding in October 1902 to 1912 (Wachsmuth, 1989). Just over half of the Anglo-books in Steiner's library are Theosophy books (164 out of 327) (Figure 3). It was Theosophy that gave Steiner his 'break', his opportunity to voice his thoughts to an engaged audience of seekers. After a decade he split with the Theosophists and founded the Anthroposophical Society in 1912 (Wachsmuth, 1989). The leading theosophists of the day are prominently represented in Steiner's library and what is clear is that he continued to actively acquire Theosophy titles for the following several decades. Leading Theosophists represented in Steiner's personal library include: Annie Besant (1847-1933) (n=61), Charles Lead beater (1854-1934) ( $\mathrm{n}=13$, two of these are co-authored with Besant), William Westcott (18481925) ( $n=13)$, Helena Blavatsky (1831-1891) $(n=10)$, and Bhagawan Das (1869-1958) $(n=4$; but $n=9$ if we allow 'The Dreamer' $(\mathrm{n}=5)$ as a pseudonym of Das') (Figure 5). None of the books by Besant, Lead beater, Westcott and Blavatsky were identified as inscribed by the author. Besant writes in her book What Theosophy is that: "The justification of the Theosophical propaganda lies in the present condition of Christendom, to say nothing of the condition of Eastern lands. The wars, the labor strife, the heartbreaking poverty, the unbrotherly competition, the brutality, the prostitution, the drunkenness - all these evils are rife in a civilization that calls itself Christian. And those who love man, who seek for the progress of the race, cannot but welcome into the field as allies in their warfare against sin and sorrow those who bring in their hands the priceless weapon of a knowledge which explains man's nature and the nature of the universe, and so opens up the road to his final triumph ... The first principle to grasp is the Esoteric Philosophy - spoken of as Theosophy in modern times" (Appendix A \#70, c.1920s, p.2). 
Figure 5: The Distribution by Author of Theosophy Anglo-Books in the Personal Library of Rudolf Steiner ( $\mathrm{N}=164)$, ( 2 books have dual authors, Besant \& Lead beater).

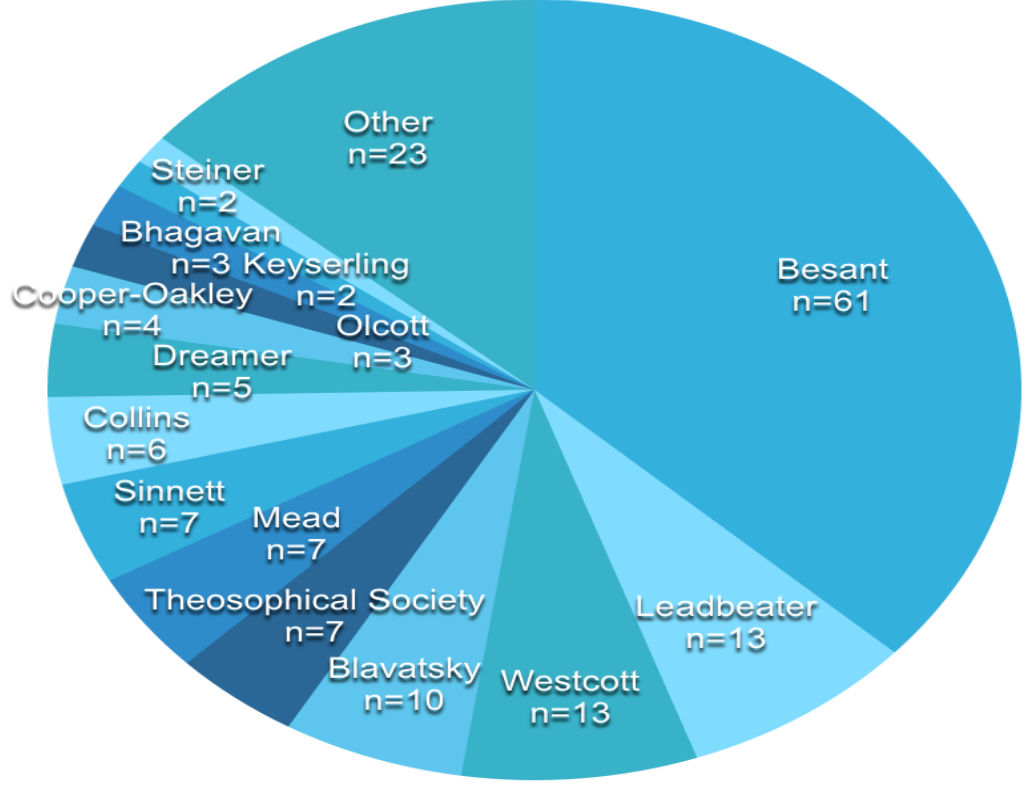

Religion (n=67): The second most populated category of Anglo-books in Rudolf Steiner's personal library is Religion (n=67) (Figure 3). The Anglo-books on Theosophy (see §3.2.3) and Anthroposophy (see §3.2.8) are dealt with separately (and are not accounted for in the Religion category). Books in this category reflect the wide-ranging interests of Steiner. Included are Anglo-titles about Christianity, Catholics, Anglicans, Jesuits, Rosicrucian's, Freemasons, Occultism, angels, incarnation, and Vedanta. There is a set of lectures to the British House of Lords by Lord Seaton on The New Religion (\#262). Steiner's library contains two books by the New Age Religionist American, Mary Baker Eddy (1821-1910): Rudimental Divine Science (1898) and Science and Health: With Key to the Scriptures (1900) (Appendix A, \#s 133, 134). Both books are out of copyright and are available free on the WWW from gutenberg.org. Eddy's battleground of ideas was the USA. She wrote at least 15 books, attracted many followers and founded the Church of Christ, Scientist. The headquarters is in Boston, Massachusetts. In the earlier book (\#133), Eddy wrote of "Divine Science" and in the later book of "Christian Science'. Her book Science and Health is her most influential work. In it she champions 'Christian Science'. There are numerous parallels (and many differences) between Eddy and Steiner. They both recognized the prevailing zeitgeist of the times as 'science' and sought to couple it with their personal take on spirituality; it was 'Christian Science' for Eddy, and 'Spiritual Science for Steiner. Both characterized the propagation of their ideas as a 'Movement'. Both attracted devoted followers and made some enemies along the way. Both established impressive imposing and architecturally distinctive headquarters (Eddy in Boston, Massachusetts, and Steiner in Dornach, Switzerland). Both envisioned their respective movements spreading beyond their own shores (that has been fulfilled for both to a limited extent). Eddy demonstrated in the USA that there was an appetite for New Age thinking and she harnessed fresh characterizations of Christian precepts. Steiner did something similar in Europe and may have taken some inspiration from Eddy's success (and perhaps lessons from her tribulations).

Social Sciences $(\mathbf{n}=33)$ : Steiner's books in the Social Sciences category reveal his broad interests and his engagement with the issues of the times, with titles on social change, women, labour, economics and war $(n=33)$ (Figure 3). The library contains five books published by the International Congress of Women which was held in London in 1899 (\#163, 164, 165, 166, and 167). The Congress was convened by the International Council of Women. The first such Congresses were held in Paris in 1878. The Congresses were a kind of women-of-the-world-unite collaboration, and they aimed to secure the right to vote for women, to give women a united voice, to show solidarity, and to share campaign tactics. The Congress of 1914 was scheduled for Berlin but it was cancelled due to the outbreak of war. The women of Holland took up the initiative (relinquished by the women of Berlin) to reconvene the Congress at The Hague with the new imperative of stopping the war (rather than women's suffrage). 
The sole Italian representative at The Hague Peace Congress of 1915 was the Anthroposophist Rosa Genoni (Paull, 2018c). The Great War (1914-1918) (WW1) was the catastrophe of the era and it left 18 million dead. There was a scramble to understand it, to propagandize it, to report it, and to blame-shift. Books of the time make curious reading a century later (and in the light of subsequent German and world history). Dehn's 1914 book, Truth about Germany: Facts about the War was published in New York and it was addressed to Americans (remembering that the USA was late into the war, joining on the side of the Entente only in 1917). Dehn asserted, of Germany, that: "Not one human being amongst us dreamt of war. We are a nation that wishes to lead a quiet and industrious life ... you Americans. You, of all others, know the temper of the German who lives within your gates. Our love of peace is so strong ... Never would a German government dare to contemplate a war for the sake of dynastic interest, or for the sake of glory ... Do not believe the mischievous lies that our enemies are spreading about! ... Who is responsible for the war? Not Germany!" (\#124, pp. 5-10).

The German Government (1914) published The German White-Book: How Russia and her Ruler Betrayed Germany's Confidence and Thereby Caused the European War (\#146). This booklet (in English) was published in Berlin and is a translation of the booklet published in German: Das Deutsche Weißbuch. This booklet reports that Russia's Tzar Nicholas urged restraint and foresaw that a prospective European war would be a "calamity". Germany's Emperor Wilhelm foresaw such a European war would be "the most terrible war it has ever seen". This booklet presents a timeline of how the war was blundered into and the apologetics of the war from the perspective of the German Government. The White-Book reported: "On June 28 [1914] the Austro-Hungarian successor to the throne, Arch-Duke Franz Ferdinand, and his wife, the Duchess of Hohenberg, were assassinated by a member of a band of Servian [=Serbian] conspirators" (\#146, p.3). "We were perfectly aware that a possible warlike attitude of Austria-Hungary against Servia [=Serbia] might bring Russia upon the field, and that it might therefore involve us in a war, in accordance with our duty as allies. We could not, however, in these vital interests of Austria-Hungary, which were at stake, advise our ally to take a yielding attitude not compatible with his dignity, nor deny him our assistance in these trying days" (\#146, p.4)

The White-Book continued: "We, therefore, permitted Austria a completely free hand in her action towards Servia but have not participated in her preparations" (RSA\#146, p.5). "From this moment Austria was in fact in a state of war with Servia, which it proclaimed officially on the 28 of July by declaring war ... We emphatically took the position that no civilized country possessed the right to stay the arm of Austria in this struggle with barbarism and political crime, and to shield the Servia against their just punishment" (\#146, p.6). The White-Book quoted Russia's Tzar Nicholas writing to German Emperor Wilhelm: "An ignominious war has been declared against a weak country and in Russia the indignation which I fully share is tremendous. I fear that very soon I shall be unable to resist the pressure exercised upon me and that I shall be forced to take measures which will lead to war. To prevent a calamity as a European war would be, I urge you in the name of our old friendship to do all in your power to restrain your ally from going too far. July 29 [1914] signed: Nicolas” (\#146, p.44). Germany's response: “To the Tzar: I cannot — as I told you in my first telegram - consider the action of Austria-Hungary as an 'ignominious war'. Austria-Hungary knows from experience that the promises of Servia as long as they are merely on paper are entirely unreliable. According to my opinion the action of Austria-Hungary is to be considered as an attempt to receive full guaranty that the promises of Servia are effectively translated into deeds. In this opinion I am strengthened by the explanation of the Austrian cabinet that Austria-Hungary intended no territorial gain at the expense of Servia.

I am therefore of the opinion that it is perfectly possible for Russia to remain a spectator in the Austro-Servia war without drawing Europe into the most terrible war it has ever seen. I believe that a direct understanding is possible and desirable between Your Government and Vienna, an understanding which - as I have already telegraphed you - my Government endeavors to aid with all possible effort. Wilhelm 29 July [1914] (\#146, p.45) Austria-Hungary declared war on Serbia on 28 July 1914. Germany declared war on Russia on 1 August. Germany invaded neutral Belgium on 4 August. The point of no return had been passed and interlocking treaties and militaristic bombast tipped others into the maelstrom which engulfed the world, until 1918. Steiner did not take a pacifist stance or a condemnatory stance during the war. He published his own Thoughts during the Time of War (Steiner. 1915). It was not out of step with published German Government views. Steiner wrote that "The warrior is steeled by the awareness that he is fighting for the most precious 
good that the earth has to give to mankind ... out of blood and death, the development of mankind will rise to aims for which the sacrifices were necessary, and which will justify them" (p.3).

Steiner's library contains three copies of Sergei Nil us The Jewish Peril: The Protocols of the Learned Elders of Zion (Appendix A, \#s 230, 231, 232). The book was controversial in its day, and probably remains so today, more than a century after its publication. The Preface addressed claims that it was a forgery. The Preface of the Fifth edition states: "it must be borne in mind that Nil us first published the Protocols in 1902; that the edition from which our translation was made was published in 1905, and that the actual copy which was used in the translation is now in the British Museum, having stamped on it the date of its reception, 10th August, 1906. There is no getting over these dates, which prove that the World War, the crucifixion of Russia, strikes, revolutions and assassinations, have all taken place 'according to plan.' And that plan was not the plan of Germany, nor the plan of England, nor the plan of any other nation except the Nation of Jewry, with its secret language and secret government - The Hidden Hand - now, at length, completely revealed in the Protocols, which, it need hardly be said, were never intended for Gentile eyes to see" (Preface in Nilus, 1921b, p.2). Consistent with the claim of a copy in the British Library, there is a copy, in Russian, of the Protocols (viz. Nilus, 1905). There is a further copy, in the British Library, also in Russian, published several years later, but still prior to the Great War (viz. Nilus, 1911). When the Protocols appeared in English its authenticity was attacked (e.g. by Wolf, 1920) and defended (e.g. by the author Nilus, 1921a). The Preface declared that: "Of course, Jews say the Protocols are a forgery. But the Great War was no forgery; the fate of Russia is no forgery; and these were predicted by the Learned Elders as long ago as 1901. The Great War was no German war - it was a Jew war. It was plotted by Jews, and was waged by Jewry on the Stock Exchanges of the world. The generals and the admirals were all controlled by Jewry.

The revelations of the Jutland Battle and its sequel give one small example of how the Jews conducted the war, whether by land or sea; how they secured the 'profits' of the war for Jews, and how they obtained controlling power for Jewry over all the belligerents" (Preface in Nilus, 1921b, p.2). During the years of WW1, Steiner continued to travel and lecture, but he did not venture beyond the bloc of the Central Powers. Civilian travel was restricted during the course of the war and, travelling on an Austrian passport Steiner would have been officially confined to the Central Power bloc and excluded from the countries of the Entente. During WW1, Steiner lectured in Germany (Berlin, Stuttgart, Nuremberg, Elberfeld, Dusseldorf, Munich, Hamburg, Kassel, and Leipzig), and in Austria-Hungary (Vienna, Prague and Linz). In neutral Switzerland most lectures were at Dornach, with others at Bern, Liestal and St Gallen. His first visit to Britain after the war was in April 1922 to Stratford-on-Avon (Paull, 2013; Villeneuve, 2004). Just a decade after Steiner's death, the Anthroposophy Society was banned in Germany (in 1935) and the Waldorf schools in Germany were progressively closed down.

Philosophy (n=21): Steiner's Anglo-books on Philosophy $(n=21)$ (Figure 3) include four books inscribed by the author John Stuart Mackenzie, British philosopher and Anthroposophist (\#s 205, 206, 207, 208) and one by his wife Millicent Mackenzie on Hegel (\#209). Steiner's library hosts a copy of the Critical and Miscellaneous Essays (1888) (\#98) by Scottish philosopher and historian Robert Carlyle (1795-1881). The book is dominated by Germanic themes; it includes five essays on Goethe, one on Schiller, and twelve other essays variously on German poets, writers, history and literature. There are two books about Plato (\#s 136, 202), one on Yoga Philosophy (\#305), and there are Volumes 1 and 2 of Pryns Hopkins' (1919) Philosophy of Helpfulness (\#s 161, 162).

Science $(\mathbf{n = 1 3})$ : The Anglo-books on Science $(n=12)$ (Figure 3) are an eclectic mix ranging across a broad spectrum of the sciences. The works include Roger Bacon's The Opus Majus, Volumes 1, 2, 3 (English \& Latin), written in the thirteenth century (Appendix A, \#s 5, 6, 7). There are other works on light and colour (\#4), biology and personality (\#11), botany (\#104), science fiction (\#s 156,157,158), iridology (\#178), astronomy \#182), cosmology (\#290), geology (\#292), and physics (\#323).

Anthroposophy (n=11): There are 11 books on Anthroposophy (Figure 3) in Steiner's library. Ten of these are by Steiner himself they are Anglo-editions, translations of works previously published in German. The remaining Anthropop-book is by his acolyte and translator, George Kaufmann, Fruits of Anthroposophy: An Introduction to the Work of Rudolf Steiner (\#170). George Kaufmann was a remarkable linguist who 
translated over a hundred of Steiner's lectures to English-speaking audiences, beginning with the teachers conference at Dornach in December 1921 and quickly followed by the Stratford-on-Avon and Oxford visits of 1922 (Adams, 1958, p.11; Paull, 2011, 2013) and translated Steiner's writings into English, including The Agriculture Course (Steiner, 1924a). Kaufmann was the son of an Australian father and an English mother. He was born on the oilfields of Eastern Europe and educated at boarding school in England and took a degree in chemistry at Cambridge University. Kaufmann was a Quaker, a pacifist, and in 1940 changed his name to Adams, his mother's maiden name. In Fruits of Anthroposophy, Kaufmann writes: "This book is an attempt to meet a need that is making itself more and more widely felt ... The number of those who have come to respect this great thinker ... is considerable. In recent years the Anthroposophical Movement of which he is the leader has come into evidence as an active spiritual force in European life, a Centre of fruitful pioneering work in almost every sphere ... considerable interest has lately been aroused on this side of the Channel, in America, and in the Colonies" (Kaufmann, 1922, p. v).

History (n=9): Steiner's nine Anglo-books in the History category (n=9) (Figure 3) include Ancient Egypt ( $n=3$ : \#s 93, 94, 322) and FG contemporary biography ( $n=3)$. There are single works on the histories of England (\#148), Poland (\#203), and the Rosicrucian's (\#321). There are three works of contemporary biography (\#s 96, 183, 291). Emily Cape's account of Lester F Ward (\#96) (inscribed to Steiner by the author) has the hallmarks of a work of adulation, if not infatuation: "For several years I was closely associated with DR Ward as co-editor ... Month after month I worked with him ... I found in the wonderful and beautiful friendship thus developed a revelation of qualities of mind and heart which could be perceived only through intimate and harmonious relations. Naturally I learned much about the man and of his life. From the many letters and much data in my possession I shall be able to offer a more intimate portrait ... and many of his thoughts never before in print. Dr. Ward's emotional nature was sublime, and only one knowing him through the heart as through the brain, realized how the following pages will reveal that nothing is truer of Lester $\mathrm{F}$. Ward than that he had: 'The mind of a sage, the heart of a woman, the soul of a poet"'.

At the outset, Rabindranath Tagore in his My Reminisces (\#291) distances his flavor of autobiography from history, he writes: "I know not who paints the pictures on memory's canvas; but whoever he may be, what he is painting are pictures; by which I mean that he is not there with his brush simply to make a faithful copy of all that is happening. He takes in and leaves out according to his taste. He makes many a big thing small and small thing big. He has no compunction in putting into the background that which was to the fore, or bringing to the front that which was behind. In short he is painting pictures and not writing history (p.1). Countess Marie Larisch in My Past (\#183) presents an autobiographical account of various goings on, intrigues and scandals in the Bavarian and Austrian Royal families: "I was educated at home and hated all of my many excellent and long-suffering governesses. I learned to fence and to ride six horses a day, and I was certainly to all intents and purposes a very boyish girl. After the war of 1866 we went to live in Munich, first at a house in the town, and then at my father's own palace; there more teachers worried me and were worried by me, but I succeeded in acquiring a fair knowledge of Latin" (p.6).

Arts (n=9): There are a small number of Anglo-books in the Arts category (n=9) (Figure 3). Most of these are catalogues and guides, including exhibition catalogues $(n=6)$. These include: British Museum: A Guide to Babylonian and Assyrian Antiquities (\#87), and catalogues from the Victoria \& Albert Museum (\#303), the Wallace Collection of Old Masters (\#306), the exhibition of Russian Theosophist artist Nicholas Roerich (\#86), and a Hollyer catalogue of reproductions (\#159). Two of Steiner's Anglo-books on the Arts are lectures. There is a lecture on painting with sound, presented to the Linnean Society, London (\#8) and an Oxford Professor of Poetry's rather turgid lecture titled The Art of Poetry (\#171). There is Walter Pater's The Renaissance: Studies in Art and Poetry (1909) (\#243). Pater writes that: "Many attempts have been made by writers on art and poetry to define beauty in the abstract, to express it in the most general terms, to find a universal formula for it. The value of these attempts has most often been in the suggestive and penetrating things said by the way.

Such discussions help us very little to enjoy what has been well done in art or poetry, to discriminate between what is more and what is less excellent in them, or to use words like beauty, excellence, art, poetry, with a more precise meaning than they would otherwise have. Beauty, like all other qualities presented to human experience, is relative; and the definition of it becomes unmeaning and useless in proportion to its 
abstractness. To define beauty, not in the most abstract, but in the most concrete terms possible, to find, not a universal formula for it, but the formula which expresses most adequately this or that special manifestation of it, is the aim of the true student of aesthetics" (Preface, \#243). Pater continues: "What is important, then, is not that the critic should possess a correct abstract definition of beauty for the intellect, but a certain kind of temperament, the power of being deeply moved by the presence of beautiful objects. He will remember always that beauty exists in many forms.

To him all periods, types, schools of taste, are in themselves equal. In all ages there have been some excellent workmen, and some excellent work done. The question he asks is always: - In whom did the stir, the genius, the sentiment of the period find itself? where was the receptacle of its refinement, its elevation, its taste? 'The ages are all equal,' says William Blake, 'but genius is always above its age."' (Preface, \# 243) Steiner was keenly interested in art. He wrote: "anthroposophy is not only a theoretical conception of the world, but from its nature gives rise to a special style of art" (quoted in Wachsmuth, 1958, p.188). Steiner developed his own distinctive styles of art (Paull, 2016), architecture (Steiner, 1914), sculpture (Selg, 2009), and dance (Spock, 1980; Steiner, 1923). Steiner encouraged visiting artists to paint in the 'Anthroposophic style' (Paull, 2016). He designed many buildings at Dornach, Switzerland, and his architectural masterpiece is the remarkable Goetheanum. It is Steiner's creation, the Goetheanum that perhaps best epitomizes what Pater wrote in 1909 of as "genius" that "is always above its age" (\#243).

\section{Discussion and Conclusion}

Despite the public persona of Rudolf Steiner as thoroughly German, the present paper reveals that his library, while predominantly German as we would expect, also contained some hundreds of books in English as well as other languages less well represented. The Anglo-books identified in the present study reveal a Rudolf Steiner very engaged with the Anglo-sphere of publishing. The wide variety of topics reveals a Steiner whose intellectual curiosity ranged widely. His remarkable and extensive personal collection of Theosophy imprints reveals his abiding interest and curiosity in all things Theosophy. The 327 books identified in the present study should be regarded as a lower bound of the Anglo-books in Steiner's personal library; for reasons of constraints of time and access it may be that some Anglo-books of the library have escaped this listing, and that offers an opportunity for supplementary further research. Perhaps a personal library, acquired over a lifetime, is a window to the soul. In any event, there are conclusions that can be drawn from the present tally of Steiner's English language books, and from these Anglo-holdings within the context of his total library: Firstly, it is clear that Steiner was actively engaged with Anglo acquisitions right up to the time of his passing.

His books include items published up to and including the final year of his life (viz.1925). Secondly, it is clear that Steiner preferred a book translated into his native language of German where that was available. Where no such translation was available he acquired books of interest in the original language. Thirdly, Steiner maintained a keen interest in Theosophy right to the end of his life. His departure from the Theosophy Society and his founding of the Anthroposophical Society as a breakaway entity in 1912 appears to have not diminished in any way his interest in Theosophy and the Theosophists. The Theosophists turned eastward in their spiritual quest, drawing heavily on Hindu and Vedic thought and establishing their headquarters in Adyar, Madras (now Chennai, capital of Tamil Nadu state, India). Steiner's teachings drew heavily on Christian themes but he also drew on Vedic traditions and Sanskrit terminology. There were many lectures on karma, he talked of the world as Maya (illusion), and he would prescribe a mantra for a seeker. Sanskrit terms used by Steiner include kamaloca, kundalini and pralaya. Steiner also talked of reincarnation, a core concept in the canon of Anthroposophy, but an idea much more firmly embedded in Eastern thought rather than Christian tradition.

Fourthly, a consideration of Steiner's library can, and ought to, inform future biographers and revise current analyses. For example, Landenberg (2017, p.471), writes of the Treaty of Versailles (of 1919) that: "To challenge this unilateral assignment of guilt [to Germany], Steiner demanded ... 'an unvarnished' report of the events leading up to the outbreak of war ... there should be a simple report of what took place, step by step, hour to hour. Such a report ... would also show just how surprised everyone was by the sequence of events ... Rudolf Steiner hoped ... that a straightforward documentation of the events would show that the initiative to begin a war had not originated in Germany". What purports to be just such a report was in Steiner's library 
(\#146). It offers no support for Landenberg's contention of "just how surprised everyone was by the sequence of events". Fifthly, the diversity of books reveals the breadth of Steiner's interests and engagement with a broad spectrum of topics including spiritual matters, religion, arts, science, politics, and history. These topics were woven into his lectures and books. Sixthly, the Anglo-books offer a small window, or perhaps just a key-hole glimpse, into the mind of Rudolf Steiner. What is clear is that further research into Steiner's personal library is warranted and will reveal fresh insights into the life and times of this remarkable individual. Rudolf Steiner's personal library was collected over five decades, spanning the closing decades of the nineteenth century and the opening decades of the twentieth century.

\section{Acknowledgements}

The hospitality and kind assistance of the staff and archivists of the Rudolf Steiner Archive (Rudolf Steiner Archiv) at Dornach, Switzerland, is acknowledged with thanks. It is, instead, a most personal and idiosyncratic collection. What makes it particularly interesting, and worthy of the present study as well as further study, is (a) its owner and (b) the fact that it has been 'frozen-in-time' and preserved intact for the best part of a century after the owner's death. This library cannot be regarded in any way as a typical personal library of the era.

\section{References}

Adams, G. (1958). Rudolf Steiner in England. In A. Freeman \& C. Waterman (Eds.), Rudolf Steiner: Recollections by Some of his Pupils (pp. 1-21). London: The Golden Blade.

Caniglia, G. (1922). Note sul Riordinamento dell' amministrazione coloniale. Bologna: Nicola Zanicehlli (RSA\# G 0124).

Cheftele, S. (1920). Les forces Morales aux etats-unis. Paris: Payot \& Cie (RSA\# G 0141).

Collison, H. (1925). Rudolf Steiner. X a.m. 30th March, 1925, R.I.P. Anthroposophical Movement, 2(13), 101.

Colombo, P. (1921). La Questione Sociale nel Pensiero die Rudolf Steiner. Milano: S.A Stamperia \& Tiporgrafia Industriale (RSA\# A 035).

Flood, A. (2017). Water ship down authors' personal library reveals precious treasures: Richard Adams's books, going to auction in December, include a first edition of Jane Austen's Emma, Shakespeare's Second Folio and Boswell's Life of Johnson. The Guardian, Tuesday 21 November.

Fludd, R. (1687). Fasciculus Geomanticus in quo Varia Variorum Opera Geomantica Continetur: Opus maxime curiosum, a multis hactenus desideratum, nunc vero magno studio correctum \& ex parte jam prima vice editum. Veronae: np (RSA\# 0 104a).

Fontane, T. (1915). Der Englische Charakter heute wie gestern. Berlin: S. Fischer.

Genoni, E. (c.1970). Personal memoir. 9 pp., typewritten manuscript, last date mentioned is 1966, A4. Private collection.

Genoni, R. (1924). La Storia della Moda Attraverso i Secoli, Volume Primo. Bergamo: Instituto Italiano D'Arti Grafiche.

Hare, W. L. (1922). An Impression of Dr. Rudolf Steiner. Occult Review (October), 215-222.

Hellberg, E. (1922). Telepati och Ockultism: En Bok for Vardagsmänniskan. Stockholm: Lars Hökerberg (RDA\# 0 162).

Kaufmann, G. (Ed.). (1922). Fruits of Anthroposophy: An Introduction to the Work of Dr Rudolf Steiner. London: The Threefold Commonwealth.

Keller, W. (1915). Das Moderne England. Münster: Borgmeyer \& Co (RSA\# W 159).

Lindenberg, C. (2017). Rudolf Steiner: A Biography. Great Barrington, MA: Steiner Books.

Maday, A. d. (1913). Sociologie de la Paix. Paris: M. Giard \& E. Briere (RSA\# G 0558).

Miles, J. (2018). St Petersburg: Three Centuries of Murderous Desire. London: Windmill Books.

Nilus, S. А. (1905). Великое въ маломъ и Антихристъ, какъ близкая политическая возможность. Записки Православнаго. Изданіе второе, еtс. Царское Село: Типографія Царскосельскаго Комитета Краснаго Креста. (British Library catalogue entry; System number 0026599520; 417 pp.)

Nilus, S. А. (1911). Близъгрядущій Антихристъ. [А revised edition of part 12 of Великоевъмаломъ, containing the text of the Протоколы. With notes and additional matter.]. Москва. (British Library catalogue entry; System number 002659953; 168 pp.).

Nilus, S. A. (1921a). 4 Protocols of Zion, not the Protocols of Nilus. [A defence of the authenticity of the 
"Protocols of the Learned Elders of Zion" published by S. A. Nilus.]. London: The Britons. (British Library System number 004023643; 21 pp.).

Nilus, S. A. (1921b). The Jewish Peril: The Protocols of the Learned Elders of Zion. (Fifth edition). London: The Britons.

Paull, J. (2010). A postcard from Oxford: Rudolf Steiner at Manchester College. Journal of Bio dynamics Tasmania, 100, 6-13.

Paull, J. (2011). Rudolf Steiner and the Oxford Conference: The birth of Waldorf education in Britain. European Journal of Educational Studies, 3(1), 53-66.

Paull, J. (2012). Tintagel: In the footsteps of Rudolf Steiner. Journal of Bio-Dynamics Tasmania, 107, 12-16.

Paull, J. (2013). Stratford-on-Avon: In the footsteps of Rudolf Steiner. Journal of Bio dynamics Tasmania, 111, 12-18.

Paull, J. (2016). The Anthroposophic Art of Ernesto Genoni, Goetheanum, 1924. Journal of Organics, 3(2), 1-24.

Paull, J. (2018a). The Home of Rudolf Steiner: Haus Hansi. Journal of Bio dynamics Tasmania, 126, 19-23.

Paull, J. (2018b). Torquay: In the Footsteps of Rudolf Steiner. Journal of Bio dynamics Tasmania, 125, 26-31.

Paull, J. (2018c). The Women Who Tried to Stop the Great War: The International Congress of Women at The Hague 1915. In A. H. Campbell (Ed.), Global Leadership Initiatives for Conflict Resolution and Peace building (pp. 249-266). (Chapter 12) Hershey, PA: IGI Global.

Peri, A. (2017). The War Within: Diaries from the Siege of Leningrad. Cambridge, MA: Harvard University Press.

Peryer, W. (1896). Darwin. Berlin: C.G. Luderitz'sche.

Piaget, J. (1915). La Mission de l'Idée. Lausanne: Edition La Concorde (RSA\# P 0808).

Robinson, J. (1970). The Cultural Revolution in China. New York: Putnam.

Schlaf, J. (1897). Walt Whitman (Vol. Vig Kreisende Ringe (Max Spohr)): Leipzig.

Schultze, E. (1915). Englische Denktragheit. Munchen: Ernst Reinhardt.

Selg, P. (2009). The Figure of Christ: Rudolf Steiner and the spiritual intention behind the Goetheanum's central work of art. Forest Row, UK: Temple Lodge Publishing.

Spock, M. (1980). Eurythmy. Spring Valley, NY: The Anthroposophic Press.

Steiner, R. (1914). Ways to A New Style in Architecture: Five lectures by Rudolf Steiner given during the building of the First Goetheanum, 1914. (First published in English in 1927). London: Anthroposophical Publishing Company.

Steiner, R. (1915). Gedanken während der Zeit des Krieges: Fuer Deutsche und diejenigen, die nicht glauben, sie hassen zu muessen (Thoughts During the Time of War: For Germans and those who do not believe they must hate them). Berlin, Philosophisch-Anthroposophischer Verlag.

Steiner, R. (1922). Spiritual Ground of Education: Nine Lectures given at Manchester College, Oxford, from August 16th to 25th, 1922 (Published in 1947 ed.). London: Anthroposophical Publishing Company.

Steiner, R. (1923). A Lecture on Eurythmy, given at Penmaenmawr on 26th August, 1923 (This edition 1977; previous editions published in 1926 \& 1967 ed.). London: Rudolf Steiner Press.

Steiner, R. (1924a). Agriculture Course ("Printed for private circulation only"; 1929, first English language edition; George Kaufmann Trans ed.). Dornach, Switzerland: Goetheanum.

Steiner, R. (1924b). Landwirtschaftlicher Kursus gehalten zu Koberwitz 7. bis 16. Juni 1924. Dornach: Herausgegeben von der naturwissenschaftlichen Sektion am Goetheanum.

Steiner, R. (1924c). The Kingdom of Childhood: Seven Lectures and Answers to Questions Given in Torquay, August 12-20, 1924 (Published thus in 1995; there are earlier editions in 1964, 1974 \& 1982 ed.). Great Barrington, MA: Anthroposophic Press.

Stern, J. (Ed.). (1981). Lewis Carroll's Library: A facsimile edition of the catalogue of the auction sale following C. L. Dodgson's death in 1898, with facsimiles of three subsequent booksellers' catalogues offering books from Dodgson's library. Silver Spring, Md: The Lewis Carroll Society of North America.

Tolstoi, L. N. (1906). Shakespeare. Hannover: Adolf Sponholtz.

Villeneuve, C. (2004). Rudolf Steiner in Britain: A Documentation of his Ten Visits, Volume 1, 1902-1921. Forest Row, UK: Temple Lodge.

Vissering, G. (1920). Over den International en Financieelen en Economischen. Amsterdam: J.H. de Bussy (RSA\# G 0928).

von Arnim, C. \& von Arnim, I. (1988). Correspondence and Documents 1901-1925 Rudolf Steiner Marie Steiner von Sivers. London: Rudolf Steiner Press.

Wachsmuth, G. (1958). The Last Years. In A. Freeman \& C. Waterman (Eds.), Rudolf Steiner: Recollections by 
Some of his Pupils (pp. 155-169). London: The Golden Blade.

Wachsmuth, G. (1989). The Life and Work of Rudolf Steiner (O. D. Wannamaker \& R. E. Raab, Trans. 2nd edition; first published in German 1941 ed.). Blauvert, NY: Spiritual Science Library.

Wagner, A. (1914). Gegen England. Berlin: Boll u Pickhardt.

Wolf, L. (1920). The Jewish Bogey, and the Forged Protocols of the Learned Elders of Zion. [Published by N. S. Nilus. A reply to articles in "The Morning Post" on "The Causes of World Unrest."]. (British Library System number 003963035; 48 pp.). London: Jewish Board of Deputies.

\section{Appendix A: List of Books in English in the Library of Rudolf Steiner}

\#1. American Section of the Theosophical Society. (1909). A Primer of Theosophy: A Very Condensed Outline. Chicago: The Rajput Press 1909 (RSA\# 0 652) (Theosophy).

\#2. American Section of the Theosophical Society. (1909). A Primer of Theosophy: A Very Condensed Outline. Chicago: The Rajput Press 1909 (RSA\# 0 652a) (Theosophy).

\#3. Archer, W. (1916). Colour-Blind Neutrality. London - New York - Toronto: Hodder \& Stoughton (RSA\# W 007) (Social Sciences).

\#4. Babbit, E. (1896). The Principles of Light and Color (New Jersey - London: Edwin Babbit (RSA\# 0 021) (Science).

\#5. Bacon, R. (1900). The Opus Majus: Volume I. London - Edinburgh - Oxford: Williams \& Norgate (RSA\# P 0036) (Science).

\#6. Bacon, R. (1900). The Opus Majus: Volume II. London - Edinburgh - Oxford: Williams \& Norgate (RSA\# P 0037) (Science).

\#7. Bacon, R. (1900). The Opus Majus: Volume III. London - Edinburgh - Oxford: Williams \& Norgate (RSA\# P 0038) (Science).

\#8. Bagley, L. (1922). Painters of Pictures in Sound. London: Simpkin, Marshall, Hamilton Kent \& Co Ltd (RSA\# L 007; Inscribed to Rudolf Steiner by the author) (Arts).

\#9. Barley, A. (1909). The Rationale of Astrology. London: Lyncroft Gardens (RSA\# O 024) (Religion).

\#10. Bathurst, L. (nd). Manifesto of the MMM ((Mysteria Mystica Maxima) London: Ballantyne Press (RSA\# 0 024a) (Religion).

\#11. Berman, L. (1922). The Glands Regulating Personality. New York: Macmillan (RSA\# Me 026) (Science).

\#12. Besant, A. (1882). Eyes and Ears. London - Benares: Freethought Publishing Company (RSA\# 0 418) (Theosophy).

\#13. Besant, A. (1891). 1875-1891: A Fragment of Autobiography. London: The Theosophical Publishing Society (RSA\# 0 401) (Theosophy).

\#14. Besant, A. (1891). 1875-1891: A Fragment of Autobiography. London: The Theosophical Publishing Society (RSA\# 0 401a) (Theosophy).

\#15. Besant, A. (1891). In Defence of Theosophy. London - New York - Benares - Madras: The Theosophical Publishing Society (RSA\# 0 424) (Theosophy).

\#16. Besant, A. (1892). The Place of Peace. London - New York - Madras: The Theosophical Publishing Society (RSA\# 0 445) (Theosophy).

\#17. Besant, A. (1893). An Autobiography. London: T. Fisher Unwin (RSA\# 0 402) (Theosophy).

\#18. Besant, A. (1893). Theosophy in Questions and Answers. London - New York - Madras: The Theosophical Publishing Society (RSA\# 0 470) (Theosophy).

\#19. Besant, A. (1894). The Meaning and the Use of Pain. London - New York - Madras: np (RSA\# O 436) (Theosophy).

\#20. Besant, A. (1894). Vegetarianism in the Light of Theosophy. London - New York - Madras: The Theosophical Publishing Society (RSA\# 0 481) (Theosophy).

\#21. Besant, A. (1895). An Introduction to Theosophy. London - New York - Benares - Madras: The Theosophical Publishing Society (RSA\# 0 426) (Theosophy).

\#22. Besant, A. (1895). Eastern Castes and Western Classes. London - Madras - Benares: The Theosophical Publishing Society (RSA\# O 412) (Theosophy).

\#23. Besant, A. (1895). Karma: Reihe Theosophical Manuals No IV. London - New York - Benares: The Theosophical Publishing Society (RSA\# 0 429) (Theosophy).

\#24. Besant, A. (1895). Materialism Undermined by Science (Volume 17 of Pamphlet Series). Benares Madras - London: The Theosophical Publishing Society (RSA\# 0 435) (Theosophy). 
\#25. Besant, A. (1895). Materialism Undermined by Science (Volume 17 of Pamphlet Series). Benares Madras - London: The Theosophical Publishing Society (RSA\# 0 435a) (Theosophy).

\#26. Besant, A. (1895). The Place of Politics in the Life of a Nation. Benares - Madras - London: The Theosophical Publishing Society (RSA\# 0 446) (Theosophy).

\#27. Besant, A. (1895). The Self and its Sheaths. Benares - Madras - London: The Theosophical Publishing Society (RSA\# 0 453) (Theosophy).

\#28. Besant, A. (trans). (1896). The Bhagavad-Gita or The Lord's Song. London - New York - Benares: Theosophical Publishing Society (RSA\# T 066) (Theosophy).

\#29. Besant, A. (trans). (1896). The Bhagavad-Gita or The Lord's Song. London - New York - Benares: Theosophical Publishing Society (RSA\# T 067) (Theosophy).

\#30. Besant, A. (trans). (1896). The Bhagavad-Gita or The Lord's Song (4th edn.). London - New York Benares: Theosophical Publishing Society (RSA\# T 067a) (Theosophy).

\#31. Besant, A. (1896). The Birth and Evolution of the Soul. London: The Theosophical Publishing Society (RSA\# 0 406) (Theosophy)

\#32. Besant, A. (1897). Four Great Religions. London - New York - Benares - Madras: The Theosophical Publishing Society (RSA\# 0 419) (Theosophy).

\#33. Besant, A. (1898). A Rough Outline of Theosophy. London - New York - Madras: The Theosophical Publishing Society (RSA\# O 452) (Theosophy).

\#34. Besant, A. (1898). In the Outer Court. London - New York - Benares - Madras: The Theosophical Publishing Society (RSA\# 0 427) (Theosophy).

\#35. Besant, A. (1898). Is Theosophy Anti-Christian? London: The Theosophical Publishing Society (RSA\# O 428) (Theosophy).

\#36. Besant, A. (1898). Is Theosophy Anti-Christian? London: The Theosophical Publishing Society (RSA\# 0 428a) (Theosophy).

\#37. Besant, A. (1898). Reincarnation. London - New York - Benares: The Theosophical Publishing Society (RSA\# 0 450) (Theosophy).

\#38. Besant, A. (1898). The Path of Discipleship. London - New York - Benares: The Theosophical Publishing Society (RSA\# O 443) (Theosophy).

\#39. Besant, A. (1899). On Some Difficulties of the Inner Life. London - New York - Benares - Madras: The Theosophical Publishing Society (RSA\# 0 440) (Theosophy).

\#40. Besant, A. (1899). The Ancient Wisdom. London: The Theosophical Publishing Society (RSA\# 0 400) (Theosophy).

\#41. Besant, A. (1899). The Doctrine of the Heart. London: The Theosophical Publishing Society (RSA\# 0 411) (Theosophy).

\#42. Besant, A. (1899). The Doctrine of the Heart. London: The Theosophical Publishing Society (RSA\# O 411a) (Theosophy).

\#43. Besant, A. (1900). Evolution of Life and Form. London - Benares: The Theosophical Publishing Society (RSA\# 0 416) (Theosophy).

\#44. Besant, A. (1900). Man and his Bodies. London - Benares - Madras: The Theosophical Publishing Society (RSA\# 0 433) (Theosophy).

\#45. Besant, A. (1900). Some Problems of Life. London - New York - Benares - Madras: The Theosophical Publishing Society (RSA\# 0 456) (Theosophy).

\#46. Besant, A. (1900). Theosophy and its Practical Application (Issue 5 of Theosophical Tracts). London: The Theosophical Publishing Society (RSA\# 0 468) (Theosophy).

\#47. Besant, A. (1901). Death and After. London: The Theosophical Publishing Society (RSA\# 0 409) (Theosophy).

\#48. Besant, A. (1901). Esoteric Christianity or The Lesser Mysteries. London - Benares: The Theosophical Publishing Society (RSA\# 0 415) (Theosophy).

\#49. Besant, A. (1902). Morning Thoughts for the Year. London - Benares: The Theosophical Publishing Society (RSA\# 0 439) (Theosophy).

\#50. Besant, A. (1902). The Three Paths and Dharma (2nd edn.). London: The Theosophical Publishing Society (RSA\# 0 475) (Theosophy).

\#51. Besant, A. (1902). Theosophy and Imperialism. London: The Theosophical Publishing Society (RSA\# O 467) (Theosophy). 
\#52. Besant, A. (1903). The Laws of the Higher Life. Benares: The Theosophical Publishing Society (RSA\# 0 431) (Theosophy).

\#53. Besant, A. (1903). The Self and its Sheaths (2nd edn. London: The Theosophical Publishing Society (RSA\# 0 454) (Theosophy).

\#54. Besant, A. (1903). Thought Power. London - Benares: The Theosophical Publishing Society (RSA\# 0 474) (Theosophy).

\#55. Besant, A. (1904). A Study in Consciousness. London - Benares - New York - Madras: The Theosophical Publishing Society (RSA\# 0 460) (Theosophy).

\#56. Besant, A. (1904). Reincarnation: A Christian Doctrine. London: The Theosophical Publishing Society (RSA\# 0 451) (Theosophy).

\#57. Besant, A. (1904). Reincarnation: A Christian Doctrine. London: The Theosophical Publishing Society (RSA\# 0 451a) (Theosophy).

\#58. Besant, A. (1904). The Necessity for Re-Incarnation. London: The Theosophical Publishing Society (RSA\# 0 442) (Theosophy).

\#59. Besant, A. (1904). The Pedigree of Man. Benares - London: The Theosophical Publishing Society (RSA\# 0 444) (Theosophy).

\#60. Besant, A. (1904). The Principle of Freethought. London: The Theosophical Publishing Society (RSA\# 0 447) (Theosophy).

\#61. Besant, A. (1904). The Principle of Freethought. London: The Theosophical Publishing Society (RSA\# 0 447a) (Theosophy).

\#62. Besant, A. (1904). The Seven Principles of Man. London - New York - Benares - Madras: The Theosophical Publishing Society (RSA\# 0 455) (Theosophy).

\#63. Besant, A. (1904). Theosophy and the New Psychology. London - Benares: The Theosophical Publishing Society (RSA\# O 469) (Theosophy).

\#64. Besant, A. (1904). When a Man Dies - Shall He Live Again. London: The Theosophical Publishing Society (RSA\# 0 484) (Theosophy).

\#65. Besant, A. (1908). A Letter to the Members of the Theosophical Society. London: np (RSA\# 0 432) (Theosophy).

\#66. Besant, A. (1908). The Work of Theosophy in the World. London: The Theosophical Publishing Society (RSA\# 0 485) (Theosophy).

\#67. Besant, A. (1912). The Growth of the T. S. Adyar, Madras: The Theosophist Office (RSA\# 0 422) (Theosophy).

\#68. Besant, A. (1912). To Members of the Theosophical Society: Being a Selection of Instructive Articles and Teachings. Adyar, Madras: The Theosophist Office (RSA\# 0 477) (Theosophy).

\#69. Besant, A. (c.1913). Theosophy and its Evidences. London - New York - Madras: The Theosophical Publishing Society (RSA\# 0 466) (Theosophy).

\#70. Besant, A. (c.1920s). What Theosophy Is. London: The Theosophical Publishing Society (RSA\# 0 483) (Theosophy).

\#71. Besant, A. \& Leadbeater, C. W. (1905). Thought-Forms. London - Benares: The Theosophical Publishing Society (RSA\# 0 473) (Theosophy).

\#72. Besant, A. \& Leadbeater, C. W. (1913). Man: Whence, How and Whither. Adyar, Madras - New York London: The Theosophical Publishing Society (RSA\# 0 434) (Theosophy).

\#73. Blavatsky, H. P. (1877). Isis Unveiled: A Master-Key to the Mysteries of Ancient and Modern Science and Theology. Volume I. New York: J W Bouton; London: Bernard Quartich (RSA\# O 501) (Theosophy).

\#74. Blavatsky, H. P. (1877). Isis Unveiled: A Master-Key to the Mysteries of Ancient and Modern Science and Theology. Volume II. New York: J W Bouton; London: Bernard Quartich (RSA\# O 502) (Theosophy).

\#75. Blavatsky, H. P. (1890). The Key to Theosophy. London - New York - Madras: The Theosophical Publishing Society (RSA\# 0 498) (Theosophy).

\#76. Blavatsky, H. P. (1890). The Secret Doctrine: The Synthesis of Science, Religion and Philosophy. Volume I. London - New York - Madras: The Theosophical Publishing Society (RSA\# 0 503) (Theosophy).

\#77. Blavatsky, H. P. (1893). First Steps to Occultism. London - Benares - Madras: The Theosophical Publishing Society (RSA\# O 508) (Theosophy).

\#78. Blavatsky, H. P. (1893). The Secret Doctrine: The synthesis of Science, Religion and Philosophy Volume II. London - New York - Madras: The Theosophical Publishing Society (RSA\# O 504) (Theosophy). 
\#79. Blavatsky, H. P. (1894). The Voice of the Silence. London - New York - Madras: The Theosophical Publishing Society (RSA\# 0 507) (Theosophy).

\#80. Blavatsky, H. P. (1895). The Secret Doctrine: The Synthesis of Science, Religion and Philosophy. Index to Volume I \& II. London - New York - Madras: The Theosophical Publishing Society (RSA\# O 506) (Theosophy).

\#81. Blavatsky, H. P. (1897). The Secret Doctrine: The synthesis of science, religion and philosophy. Volume III. London - New York - Madras: The Theosophical Publishing Society (RSA\# O 505) (Theosophy).

\#82. Blavatsky, H. P. (1907). Index to the Third Volume of Madame H. P. Blavatsky's Secret Doctrine. Auckland: The Theosophical Book Depot (RSA\# 0 506a) (Theosophy).

\#83. Bragdon, C. (1910). Episodes from an Unwritten History. Rochester, NY: The Manas Press (RSA\# 0 514) (Theosophy).

\#84. Bragdon, C. (1910). The Beautiful Necessity: Seven Essays on Theosophy and Architecture. Rochester, NY: The Manas Press (RSA\# O 515) (Theosophy).

\#85. Brailsford, H. N. (1917). The War of Steel and Gold. London: Bell \& Sons, Ltd. (RSA\# W 049) (Social Sciences).

\#86. Brinton, C. (1922). The Nicolas Roerich Exhibition 1920-1921-1922. New York: Redfield - Kendrick Odell Company (RSA\# K 157a) (Arts).

\#87. British Museum. (1900). British Museum: A Guide to Babylonian and Assyrian Antiquities. London: British Museum, By order of the Trustees (RSA\# K 114) (Arts).

\#88. British Museum. (1920). The Babylonian Story of the Deluge and the Epic of Gilgamesh. London: The British Museum (RSA\# T 133) (Religion).

\#89. British Museum. (1921). The Babylonian Legends of the Creation and the Fight Between Bel and the Dragon. London: British Museum (RSA\# T 134) (Religion).

\#90. British Museum. (1922). The Book of the Dead (2nd edn. London: British Museum (RSA\# T 132) (Religion).

\#91. Brown, G. M. (nd). Essene Order, Study Nr. 8. Denver: Essene Publishing (RSA\# 0 045) (Religion).

\#92. Brownrigg, B. (c.1922). The Well of Life: A Little Book of Thought and Prayer for Children of Twelve to Sixteen. London: Nisbet \& Co. Ltd. (RSA\# O 046) (Religion).

\#93. Budge, E. A. W. (1912). Books on Egypt and Chaldaea: Egyptian Literature. Volume II. London: Kegan Paul (RSA\# G 0099) (History).

\#94. Budge, E. A. W. (1924). The Teaching of Amen-Em-Apt, Son of Kanekht. London: Martin Hopkinson \& Co (RSA\# G 0100) (History).

\#95. Budge, E. A. W. (1925). The Egyptian Heaven and Hell. London: Martin Hopkinson \& Co (RSA\# G 0101) (Religion).

\#96. Cape, E. P. (1922). Lester F. Ward: A Personal Sketch. New York - London: The Knickerbocker Press (RSA\# A 033; Inscribed to Rudolf Steiner by the author) (History).

\#97. Carlile, R. (c.1860). Manual of Freemasonry. London: Reeves \& Turner (RSA\# O 054) (Religion).

\#98. Carlyle, T. (1888). Critical and Miscellaneous Essays. London: Chapman \& Hall (RSA\# L 045) (Philosophy).

\#99. Catchings, W. (1922). Our Common Enterprise: A Way Out for Labor and Capital (Massachusetts: Pollak Foundation for Economic Research (RSA\# G 0133) (Social Sciences).

\#100. Central Hindu College. (1903). A Catechism for Boys and Girls in Hindu Religion and Morals. Benares: Central Hindu College (RSA\# O 517) (Religion).

\#101. Challoner, H. K. (nd). The Wheel of Rebirth: Some memories of an occult student (Paternoster Row: Rider \& Co. (RSA\# O 520) (Religion).

\#102. Chambers, A. (1919). Man and the Spiritual World. London: Gay \& Hancock (RSA\# 0 056) (Religion).

\#103. Chesterfield. (1841). Practical Morality. Hartford: William Andrus (RSA\# P 0187a) (Religion).

\#104. Church, A. H. (1919). Elementary Notes on Structural Botany. London - Edinburgh - Glasgow - New York -Toronto - Melbourne - Cape Town - Bombay: Humphrey Milford OUP (RSA\# N 071) (Science).

\#105. Clutton-Brock, A. (1920). The Ultimate Belief. London: Constable \& Company (RSA\# T 157) (Religion).

\#106. Cole, G. D. H. (1920). Social Theory. London: Methuen \& Co (RSA\# G 0146) (Social Sciences).

\#107. Collins, M. (1889). Love's Chaplet. London: The Theosophical Publishing Society (RSA\# 0526) (Theosophy).

\#108. Collins, M. (1894). Light on the Path. London - New York - Madras: The Theosophical Publishing Society (RSA\# 0 525) (Theosophy). 
\#109. Collins, M. (1905). A Cry from Afar. London: The Theosophical Publishing Society (RSA\# O 532) (Theosophy).

\#110. Collins, M. (1905). Illusions. London: The Theosophical Publishing Society (RSA\# O 530) (Theosophy). \#111. Collins, M. (1912). The Occult Review. London: William Rider \& Son (RSA\# O 522) (Religion).

\#112. Collins, M. C. C. (1901). Through the Gates of Gold. London: J. M. Watkins (RSA\# O 528) (Theosophy).

\#113. Cooper, I. S. (c.1919). Methods of Psychic Development. Adyar, Madras: The Theosophist Office (RSA\# O 533) (Theosophy).

\#114. Cooper, L. M., et al. (1891). H. P. B: In Memory of Helena Petrovna Blavatsky by Some of her Pupils. London: The Theosophical Publishing Society (RSA\# 0 509) (Theosophy).

\#115. Cooper-Oakley, I. (1895). Studies in the 'Secret Doctrine'. London - New York - Madras: The Theosophical Publishing Society (RSA\# O 534) (Theosophy).

\#116. Cooper-Oakley, I. (1895). Studies in the 'Secret Doctrine'. London - New York - Madras: The Theosophical Publishing Society (RSA\# O 534a) (Theosophy).

\#117. Cooper-Oakley, I. (1909). Mystical Traditions (Milano: Ars Regia (RSA\# O 535) (Theosophy).

\#118. Cooper-Oakley, I. (1909). Mystical Traditions (Milano: Ars Regia (RSA\# O 535a) (Theosophy).

\#119. Corbet, R. W. (1889). Letters from a Mystic of the Present Day. London: Elliot Stock (RSA\# 0 007) (Theosophy).

\#120. Das, B. (1904). The Science of Peace. An Attempt at an Exposition of the First Principles of Adhyatma Vidya. Benares: proof copy (RSA\# 0 487) (Theosophy).

\#121. Das, B. (1904). The Science of Peace. An Attempt at an Exposition of the First Principles of Adhyatma Vidya. London - Benares: The Theosophical Publishing Society (RSA\# 0 488) (Theosophy).

\#122. Das, B. (1904). The Science of the Emotions. London - Benares: The Theosophical Publishing Society (RSA\# 0 486) (Theosophy).

\#123. Das, B. (1926). God and His Visions. Calcutta: A. P. Sakkar (RSA\# 0 489; Inscribed to Rudolf Steiner by the author 28 July 1926) (Religion). [Author's note: The date is an anomaly; either a posthumous addition to the library or a transcription error. This book is not listed in wordcat.org].

\#124. Dehn, P. S. (1914). Truth about Germany: Facts about the War. New York: Iron Press (RSA\# W 070) (Social Sciences).

\#125. Delitzsch, F. J. (1882). The Hebrew New Testament (4th edn. Berlin: Trowitzsch \& Sohn (RSA\# T 072) (Religion).

\#126. Douglas, C. H. M. (1922). The Control and Distribution of Production. London: Cecil Palmer (RSA\# G 0184) (Social Sciences).

\#127. Dreamer, The. (1900). On the Threshold. Calcutta: Aughore Nath Dutt (RSA\# O 542) (Theosophy).

\#128. Dreamer, The. (1902). Studies in the Bhagavad Gita: The Yoga of Discrimination. London: The Theosophical Publishing Society (RSA\# O 540a) (Theosophy).

\#129. Dreamer, The. (1902). Studies in the Bhagavad Gita: The Yoga of Discrimination. London: The Theosophical Publishing Society (RSA\# O 540) (Theosophy).

\#130. Dreamer, The. (1903). Studies in the Bhagavad Gita: The Yoga of Discrimination. London: The Theosophical Publishing Society (RSA\# 0 541) (Theosophy).

\#131. Dreamer, The. (c.1908). Another Letter to the Members of the Theosophical Society. Calcutta: np (RSA\# 0 538) (Theosophy).

\#132. Dunlop, D. N. (1920). Nature-Spirits and the Spirits of the Elements. London: Theosophical Publishing House (RSA\# A 038) (Theosophy).

\#133. Eddy, M. B. (1898). Rudimental Divine Science. Boston: Joseph Armstrong (RSA\# O 023) (Religion).

\#134. Eddy, M. B. (1900). Science and Health: With Key to the Scriptures. Boston: Joseph Armstrong (RSA\# O 022) (Religion).

\#135. Ferrier, J. T. (c.1912). The Second Coming of Christ, or The New Avatar (Bradford, London: Percy, Lund Humphries \& Co. Ltd. (RSA\# O 550) (Religion).

\#136. Ferry, P. (c.1921). The Congregation of Plato (Stone: T. G. Adie \& Co. (RSA\# O 098) (Philosophy).

\#137. Firth, F. M. (1905). The Golden Verses of Pythagoras and other Pythagorean Fragments. London Benares: The Theosophical Publishing Society; New York: John Lane; Chicago: The Theosophical Book Concern (RSA\# 0 101) (Theosophy).

\#138. Firth, F. M. (1905). The Golden Verses of Pythagoras and other Pythagorean Fragments. London Benares: The Theosophical Publishing Society; New York: John Lane; Chicago: The Theosophical Book Concern (RSA\# 0 101a) (Theosophy). 
\#139. Flagg, W., J. (1898). Yoga or Transformation. New York: J. W. Bouton; London: George Redway (RSA\# O 103) (Religion).

\#140. Fludd, R. (1659). Mosaicall Philosophy: Grounded Upon the Essential Truth and Eternal Sapience. London: Humphrey Moseley at Prince's Arms in St. Paul's Church-yard (RSA\# P 0339a) (Philosophy).

\#141. Fox, R. J. (1916). Revelation on Revelation and these Latter Days. London: Kegan Paul, Trench, Trubner \& Co. (RSA\# 0 106) (Religion).

\#142. Francis, P. (1919). The Poison in America's Cup. New York: The Little Books Library (RSA\# G 0246) (Social Sciences).

\#143. Francis, P. (1919). What's the Matter with our America? New York: The Little Books Library (RSA\# G 0247) (Social Sciences).

\#144. Fussell, J., H. (1909). Mrs. Anne Besant and the Moral Code. np: np: manuscript (RSA\# 0 553) (Theosophy).

\#145. G, G. (nd). The Secret Machinery of Revolution. London: St. Clements Press (RSA\# G 0725) (Social Sciences).

\#146. German Government (1914). The German White-Book: How Russia and her Ruler Betrayed Germany's Confidence and Thereby Caused the European War. Berlin: Liebheit \& Thiesen (RSA\# W 107) (Social Sciences).

\#147. Gibson, v. R. (c.1923). The Faith that Overcomes the World: Studies in the Way to the Higher Knowledge, Healing and Mastery of Life, Supplemented by Exercises for Practical Application. New York: The Macmillan Company (RSA\# O 134) (Religion).

\#148. Goldsmith, D. (1831). An Abridgement of the History of England (Philadelphia: James Locken (RSA\# G 0292) (History).

\#149. Gore, C. (1913). Lux Mundi: A series of Studies in the Religion of the Incarnation. London: John Murray (RSA\# T 250) (Religion).

\#150. Gray, J. (trans). (1898). Goethe's Satyros and Prometheus (Glasgow: Reihe: Publications of the Glasgow Goethe Society (RSA\# Go 219) (Philosophy).

\#151. Harris, T. L. (1880). The Holy City and the Light Therein. np: np (RSA\# 0 018) (Religion).

\#152. Hartmann, F. (1896). The Life of Philippus Theophrastus Bombast of Hohenheim known by the Name of Paracelsus and the Substance of his Teachings. London: Kegan Paul, Trench, Trubner \& Co. Ltd. (RSA\# 0 559) (Philosophy).

\#153. Heindel, M. (1909). The Rosicrucian Cosmo-Conception, or Christian Occult Science. Seattle: The Rosicrucian Fellowship (RSA\# 0 147) (Religion).

\#154. Heindel, M. (1916). The Rosicrucian Mysteries. California: The Rosicrucian Fellowship (RSA\# 0 149) (Religion).

\#155. Heindel, M. (1923). The Birth of the Rosicrucian Fellowship (California: The Rosicrucian Fellowship (RSA\# 0 148) (Religion).

\#156. Hinton, C. H. (1886). Scientific Romances (First Series London: Swan Sonnenschein \& Co. Ltd. (RSA\# N 271) (Science).

\#157. Hinton, C. H. (1902). Scientific Romances (Second Series London: Swan Sonnenschein \& Co. Ltd. (RSA\# N 271a) (Science).

\#158. Hinton, C. H. (1906). A New Era of Thought. London: Swan Sonnenschein \& Co. Ltd. (RSA\# H 270) (Philosophy).

\#159. Hollyer, F. (1906). Catalogue of Platinotype Reproductions of Pictures Etc Photographed and Sold by Mr Hollyer. London: Frederick Hollyer (RSA\# K 083) (Arts).

\#160. Hoover, H. (1922). American Individualism. New York: Doubleday, Page \& Co (RSA\# G 0370) (Social Sciences).

\#161. Hopkins, P. C. (1919). Philosophy of Helpfulness. Volume II (Minneapolis: Pioneer Printers (RSA\# P 527) (Philosophy).

\#162. Hopkins, P. C. (nd). Philosophy of Helpfulness (Minneapolis: Pioneer Printers (RSA\# P 526) (Philosophy).

\#163. ICW. (1900). The International Congress of Women '99: Women in Education. London: T. Fisher Unwin (RSA\# G 0383a) (Social Sciences).

\#164. ICW. (1900). The International Congress of Women '99: Women in Industrial Life. London: T. Fisher Unwin (RSA\# G 0383c) (Social Sciences). 
\#165. ICW. (1900). The International Congress of Women '99: Women in Politics. London: T. Fisher Unwin (RSA\# G 0383b) (Social Sciences).

\#166. ICW. (1900). The International Congress of Women '99: Women in Professions. London: T. Fisher Unwin (RSA\# G 0383) (Social Sciences).

\#167. ICW. (1900). The International Congress of Women '99: Women in Social Life. London: T. Fisher Unwin (RSA\# G 0383d) (Social Sciences).

\#168. Jagger, J. B. (1922). The Immaculate Conception. London: Catholic Truth Society (RSA\# T 324) (Religion).

\#169. James, W. (1903). The Varieties of Religious Experience. New York - Bombay: Longmans, Green \& Co. (RSA\# T 325) (Religion).

\#170. Kaufmann, G. (1922). Fruits of Anthroposophy: An Introduction to the Work of Rudolf Steiner. London: The Threefold Commonwealth (RSA\# A 054; Inscribed to Rudolf Steiner by the author) (Anthroposophy).

\#171. Ker, W. P. (1920). The Art of Poetry. Oxford: Clarendon Press (RSA\# L131) (Arts).

\#172. Keynes, J. M. (1920). The Economic Consequences of the Peace. London: Macmillan \& Co (RSA\# W 160) (Social Sciences).

\#173. Keyserling, G. H. (1912). On Belief. Adyar, Madras: The Theosophist (RSA\# O 579) (Theosophy).

\#174. Keyserling, G. H. (1912). Some Suggestions Concerning Theosophy. Adyar, Madras: The Theosophist (RSA\# 0 578) (Theosophy).

\#175. Kingsland, W. (1893). The Esoteric Basis of Christianity. London - New York - Madras: The Theosophical Publishing Society (RSA\# O 580) (Theosophy).

\#176. Kirk, E. (1894). The Influence of the Zodiac upon Human Life. Brooklyn: Eleanor Kirk (RSA\# 0 199) (Religion).

\#177. Koch, A. (1908). Sculptures. London: Academy Architecture (RSA\# K 101) (Arts).

\#178. Kritzer, J. H. (1921). Text-Book of Iridiagnosis: Guide in Treatment. Chicago: J. Haskel Kritzer (RSA\# Me 135; Inscribed to Rudolf Steiner by the author) (Science).

\#179. Labour Party (1919). The Labour Co-Partnership Association: Thirty-Fourth Report 1919. London: The Labour Party (RSA\# G 0503) (Social Sciences).

\#180. Labour Party. (1921). Report of the Labour Commission to Ireland. London: The Labour Party (RSA\# G 0504) (Social Sciences).

\#181. Labour Party. (1921). Report of the Labour Commission to Ireland. London: The Labour Party (RSA\# G 0504a) (Social Sciences).

\#182. Lamy, C. J. (1919). New Knowledge of the Earth, Sun, Moon, Planets, Stars Comets, Nebulae. New York: Willard Press (RSA\# 0 212) (Science).

\#183. Larisch, M. C. (1913). My Past. London: Eveleigh Nash (RSA\# G 0515) (History).

\#184. Lawrence, F. W. P. (1918). A Levy on Capital. London: George Allen \& Unwin Ltd, Ruskin House (RSA\# G 0521) (Social Sciences).

\#185. Leadbeater, C. W. (1897). The Aura. London - New York - Benares: The Theosophical Publishing Society (RSA\# 0 593) (Theosophy).

\#186. Leadbeater, C. W. (1900). The Astral Plane. London: The Theosophical Publishing Society (RSA\# O 584) (Theosophy).

\#187. Leadbeater, C. W. (1902). An Outline of Theosophy. London - Benares: The Theosophical Publishing Society (RSA\# O 590) (Theosophy).

\#188. Leadbeater, C. W. (1903). Life After Death: Purgatory Etc. Harrogate: The Theosophical Publishing Society (RSA\# 0 594) (Theosophy).

\#189. Leadbeater, C. W. (1903). Reincarnation. Harrogate: Theosophical Publishing Committee (RSA\# O 595) (Theosophy).

\#190. Leadbeater, C. W. (1903). Some Glimpse of Occultism. London: The Theosophical Publishing Society (RSA\# 0 582) (Theosophy).

\#191. Leadbeater, C. W. (1903). The Law of Cause and Effect. Harrogate: Theosophical Publishing Committee (RSA\# 0 597) (Theosophy).

\#192. Leadbeater, C. W. (1903). The Soul and its Vestures. Harrogate: Theosophical Publishing Committee (RSA\# 0 596) (Theosophy).

\#193. Leadbeater, C. W. (1907). Man Visible and Invisible. London: The Theosophical Publishing Society (RSA\# 0 583) (Theosophy). 
\#194. Leadbeater, C. W. (c.1899). Invisible Helpers. London: The Theosophical Publishing Society (RSA\# O 586) (Theosophy).

\#195. Leadbeater, C. W. (c.1904). The Christian Creed: Its origin and signification. London - New York Benares - Madras: The Theosophical Publishing Society (RSA\# O 591) (Theosophy).

\#196. Leo, A. (1908). How to Study Astrology. London: Modern Astrology (RSA\# O 219) (Religion).

\#197. Leo, A. (nd). Four Lectures on Astrology; Exoteric and Esoteric. Bombay: Modern Astrology (RSA\# 0 220) (Religion).

\#198. Lepicier, A. H. M. (1906). The Unseen World: An Exposition of Catholic Theology in its Relation to Modern Spiritism. London: Kegan Paul, Trench, Trubner \& Co Ltd. (RSA\# 0 222) (Religion).

\#199. Levi, E. (1913). The Equinox: The Key of the Mysteries. London: Wieland \& Co (RSA\# O 228a) (Religion).

\#200. Libra, C. A. (nd). The Meaning of Life and Evolution: To All Those Who Feel Dissatisfied and Unhappy. Los Angeles: nd (RSA\# 0 229) (Philosophy).

\#201. Louismet, D. S. (1922). The Mystery of Jesus. London: Burns, Oats \& Washbourne: New York: P. J Kennedy \& Sons (RSA\# T 407) (Religion).

\#202. Lutoslawski, W. (1897). The Origin and Growth of Plato's Logic. New York - Bombay: Longmans, Green \& Co. (RSA\# P 0705) (Philosophy).

\#203. Lutoslawski, W. (1908). The Polish Nation (Berkeley: The University Press 1908 (RSA\# G 0549) (History).

\#204. Macbeth, B. J. L. (1910). The Christ of the Holy Grail. London: The Theosophical Publishing Society (RSA\# 0 600) (Theosophy).

\#205. Mackenzie, J. S. (1907). Lectures on Humanism. London: Swan Sonnenschein \& Co: New York: The Macmillan Company/George Allen \& Unwin (RSA\# P 0713; Inscribed to Rudolf Steiner by the author) (Philosophy).

\#206. Mackenzie, J. S. (1919). Elements of Constructive Philosophy. London: George Allen \& Unwin: New York: The Macmillan Company (RSA\# P 0714; Inscribed to Rudolf Steiner by the author) (Philosophy).

\#207. Mackenzie, J. S. (1921). Outlines of Social Philosophy. London: George Allen \& Unwin; New York: The Macmillan Company (RSA G: 0557; Inscribed to Rudolf Steiner by the author) (Philosophy).

\#208. Mackenzie, J. S. (1924). Ultimate Values in the Light of Contemporary Thought. London - Toronto: Swan Sonnenschein \& Co. (RSA\# P 0715; Inscribed to Rudolf Steiner by the author) (Philosophy).

\#209. Mackenzie, M. H. (1909). Hegel's Education Theory \& Practice. London: Swan Sonnenschein \& Co (RSA\# P 0716; Inscribed to Rudolf Steiner by the author) (Philosophy).

\#210. MacNeile, E. R. (1913). Theosophy and the Coming Christ. Westminster: Society for the Propagation of the Gospel in Foreign Parts (RSA\# 0 604) (Theosophy).

\#211. MacNeile, E. R. (1913). Theosophy and the Coming Christ. Westminster: Society for the Propagation of the Gospel in Foreign Parts (RSA\# 0 604a) (Theosophy).

\#212. Marconis, J. E. \& Yarker, J. (1882). Lectures of a Chapter, Senate \& Council: According to the Forms of the Ancient Primitive Rite, but Embracing all Systems of High Grade Masonry. London: John Hogg (RSA\# 0 249) (Religion).

\#213. Marona. (c.1907). Readings from the Astral Libraries of Atlantis and Alexandria. Letchworth: Garden City Press (RSA\# 0 602) (Religion).

\#214. Marques, A. (1896). The Human Aura. San Fransisco: Office of Mercury (RSA\# O 603) (Religion).

\#215. Mead, G. R. S. (1896). Orpheus: The Theosophy of the Greeks. London - Benares - Madras: The Theosophical Publishing Society (RSA\# 0 607) (Theosophy).

\#216. Mead, G. R. S. (1896). Pistas Sophia. London - New York - Benares - Madras: The Theosophical Publishing Society (RSA\# 0 605) (Theosophy).

\#217. Mead, G. R. S. (1896). The Upanishads. London - New York - Benares - Madras: The Theosophical Publishing Society (RSA\# 0 606) (Theosophy).

\#218. Mead, G. R. S. (1896). The Upanishads. London - New York - Benares - Madras: The Theosophical Publishing Society (RSA\# 0 606a) (Theosophy).

\#219. Mead, G. R. S. (1896). The Upanishads. London - New York - Benares - Madras: The Theosophical Publishing Society (RSA\# O 606b) (Theosophy).

\#220. Mead, G. R. S. (1901). Apolonius of Tyana: The Philosopher-Reformer of the First Century. London Benares: The Theosophical Publishing Society (RSA\# O 610) (Theosophy). 
\#221. Mead, G. R. S. (1903). Did Jesus Live 100 B. C? London - Benares: The Theosophical Publishing Society (RSA\# 0 608) (Theosophy).

\#222. Mellor, S. A. (1920). Jesus Christ \& Social Change. London: The Swarthmore Press (RSA\# T 431) (Religion).

\#223. Menzies, L. (1920). Saint Columba of Iona. London - Toronto: J. M. Dent \& Sons, Ltd.: New York: E. P. Dutton \& Co. (RSA\# T 432) (Religion).

\#224. Mills, J. P. (1908). Health: Omnipresence, Omniscience, Infinite. Abstract and Concrete. London: np (RSA\# 0 257) (Social Sciences).

\#225. Milne Home, H. A. (1922). First News of the Other World, or the Wonderful History Entitled "The Venetian Virgin': A History as Startling as it is Necessary and Useful to Read and to be Understood of Any and All. Plymouth]: [J. H. Keys] (RSA\# O 291) (Religion).

\#226. Moore, G. F. (1911). Notes from India \& Co-Masonry ((Reprinted from issues of The New Age, the official organ of the Supreme Council of the Thirty Third Degree of the Ancient and Accepted Scottish Rite of Freemasonry for the Southern Jurisdiction of the United States of America, 1910 \& 1911). Point Loma, CA: The Aryan Theosophical Press (RSA\# O 261b) (Theosophy).

\#227. Murray, A. G. (trans). (c.1901). The Red Letter New Testament. London: William Collins (RSA\# T 101; Inscribed to Rudolf Steiner, London, 3 September 1905) (Religion).

\#228. Myer, I. (1900). Oldest Book in the World: An Account of Religion, Wisdom, Philosophy, Ethics, Psychology, Manners, Proverbs, Sayings, Refinement, etc., of the Ancient Egyptians. Leipzig: O. Harrasswitz; New York: E. W. Dayton; London: Kegan Paul, Trench, Trubner (RSA\# G 0613) (Religion).

\#229. Myers, F. W. H. (1904). Man and Death. Bradford: The Northern Federation Theosophical Society; London: Percy Lund, Humphries \& Co. Ltd. The Country Press (RSA\# 0 611) (Theosophy).

\#230. Nilus, S. (1920). The Jewish Peril: Protocols of the Learned Elders of Zion (2nd edn.). London: The Britons (RSA\# G 1012) (Social Sciences).

\#231. Nilus, S. (1920). The Jewish Peril: Protocols of the Learned Elders of Zion (2nd edn.). London: The Britons (RSA\# G 1013) (Social Sciences).

\#232. Nilus, S. (1921). The Jewish Peril: Protocols of the Learned Elders of Zion (4th edn.). London: The Britons (RSA\# G 1014) (Social Sciences).

\#233. Notovitch, N. (1907). The Unknown Life of Jesus Christ. Chicago: Progressive Thinker Publishing House (RSA\# T 473) (Religion).

\#234. Olcott, H. S. (1895). Old Diary Leaves: The True Story of the Theosophical Society. New York - London Madras: G. P. Putnam's Sons-The Proprietors of the Theosophical Society (RSA\# 0 613) (Theosophy).

\#235. Olcott, H. S. (1900). Old Diary Leaves: The Only Authentic History of the Theosophical Society, Third Series, 1870-1888. London - Madras: The Theosophical Publishing Society (RSA\# 0 614) (Theosophy).

\#236. Olcott, H. S. (1904). Old Diary Leaves: The Only Authentic History of the Theosophical Society, Third Series, 1883-1887. London - Madras: The Theosophical Publishing Society (RSA\# O 615) (Theosophy).

\#237. Ossendowski, F. A. (1923). Beasts, Men and Gods. London: Edward Arnold \& Co. (RSA\# 0 275) (Religion).

\#238. Ouspensky, P. D. (1913). The Symbolism of the Tarot: Philosophy of Occultism in Pictures and Numbers (trans. A.L Pogossy). St Petersburg, Russia: Trood Printing and Publishing Co. (RSA\# 0 278) (Religion).

\#239. Ouspensky, P. D. (1920). Tertium Organum: The Third Canon of Thought, a Key to the Enigmas of the World. New York: Manas Press (RSA\# 0 277a) (Social Sciences).

\#240. Ouspensky, P. D. (1923). Tertium Organum: The Third Canon of Thought, a Key to the Enigmas of the World. London: Kegan Paul (RSA\# 0 277) (Social Sciences).

\#241. Oxley, W. (1896). The Rise and Development of Religious Beliefs and Systems. London: W. Stewart \& Co. (RSA\# 0 279) (Religion).

\#242. Pande, P. B. (1911). Man: Social, Moral, Intellectual. Calcutta: The Bengal Medical Library (RSA\# 0 620) (Social Sciences).

\#243. Pater, W. (1909). The Renaissance: Studies in Art and Poetry. New York: The Macmillan Company (RSA\# K 142) (Arts). 
\#244. Patterson, H. T. (1891). The Theosophical Society \& H. P. B. London - New York - Madras: The Theosophical Publishing Society (RSA\# 0 465) (Theosophy).

\#245. Péralté, L. (1914). The First Stages of a Spiritual Movement: With a Sketch of H Blavatsky and Others. London: John M. Watkins (RSA\# 0 599) (Theosophy).

\#246. Pryse, J., M. (1909). The Magical Message, According to Iöannés. New York: The Theosophical Publishing Company of New York (RSA\# 0 622) (Theosophy).

\#247. Ramanathan, P. (1906). The Culture of the Soul among Western Nations. New York - London: G. P. Putnam's Sons (The Knickerbocker Press) (RSA\# 0 305) (Religion).

\#248. Re-Bartlett, L. (1915). The Circle and the Cross. Bombay: Longmans, Green \& Co. (RSA\# T 518) (Religion).

\#249. Rickaby, J. S. J. (nd). The Society of Jesus. London: Catholic Truth Society (RSA\# T 531) (Religion).

\#250. Roper, R. E. (1922). The Individual \& the Community. London: George Allen \& Unwin Ltd (RSA\# G 0735; Inscribed to Rudolf Steiner by the author, August 1922) (Social Sciences).

\#251. Russell, E. A. (1919). Thoughts Inspired by the A. A. Scottish Rite Degrees. Chicago: Edgar A. Russell \& Company (RSA\# 0 128) (Religion).

\#252. Sastri, A. M. (trans). (1899). The Vedanta Doctrine of Sri Sankaracharya. Madras: Thompson \& Co. (RSA\# 0 601) (Religion).

\#253. Sastri, S. S. (trans). (1898). The Isa, Kena \& Mundaka Upanishads and Sri Sankara's Commentary. Madras: G. A. Natesan \& Son Printers (RSA\# 0 658) (Religion).

\#254. Sastri, S. S. (trans). (1898). The Katha and Prasna Upanishads and Sri Sankara's Commentary. Madras: G. A. Natesan \& Son Printers (RSA\# 0 659) (Religion).

\#255. Sastri, S. S. (trans). (1899). The Aitareya \& Taiyyiri'ya Upanishads and Sri Sankara's Commentary. Madras: G. A. Natesan \& Son Printers (RSA\# 0 662) (Religion).

\#256. Sastri, S. S. (trans). (1899). The Chha'ndogya Upanishad and Sri Shankara's Commentary. Volume One. Madras: G. A. Natesan \& Son Printers (RSA\# 0 660) (Religion).

\#257. Sastri, S. S. (trans). (1899). The Chha'ndogya Upanishad and Sri Shankara's Commentary. Volume Two. Madras: G. A. Natesan \& Son Printers (RSA\# 0 661) (Religion).

\#258. SCF. (1921). Report on European Student Relief 1920-21 (Annual Report of the European Student Relief of the World's Student Christian Federation (SCF). Geneva: Student Christian Federation. (RSA\# G 0217) (Social Sciences).

\#259. Schwarz, A. (1901). The Relation of Man to God. Madras: Thompson \& Co. (RSA\# 0 624) (Religion).

\#260. Schwarz, A. (1901). The Relation of Man to God. Madras: Thompson \& Co. (RSA\# 0 624a) (Religion).

\#261. Scott-Elliot, W. (1904). The Lost Lemuria. London: Theosophical Publishing Society (RSA\# 0 625) (Theosophy).

\#262. Seaton, Lord. (c.1920s). The New Religion: Three Speeches Delivered in the House of Lords. Buckfastleigh: np (RSA\# T 579) (Religion).

\#263. Shirley, R. (c.1915). The Angel Warriors at Mons: Including Numerous Confirmatory Testimonies Evidence of the Wounded and Certain Curious Historical Parallels. London: Newspaper Publicity Co (RSA\# G 0820) (Religion).

\#264. Sinnett, A. P. (1896). Incidents in the Life of Madame Blavatsky. London: George Redway (RSA\# 0 632) (Theosophy).

\#265. Sinnett, A. P. (1898). Esoteric Buddhism. London - New York - Benares - Madras: The Theosophical Publishing Society (RSA\# 0 629) (Theosophy).

\#266. Sinnett, A. P. (1901). The Occult World. London: Theosophical Publishing Society (RSA\# 0 635) (Theosophy).

\#267. Sinnett, A. P. (1903). The Constitution of the Earth. London: Theosophical Publishing Society (RSA\# O 637) (Theosophy).

\#268. Sinnett, A. P. (1905). The Growth of the Soul. London - Benares: The Theosophical Publishing Society (RSA\# 0 634) (Theosophy).

\#269. Sinnett, A. P. (1923). The Mahatma Letters. London: T. Fisher Unwin (RSA\# 0 631) (Theosophy).

\#270. Sinnett, A. P. (c.1907). The Vicissitudes of Theosophy (np: np (RSA\# 0 638) (Theosophy).

\#271. Siva, R., A. (1904). Rules for Daily Life. Tanjore: V. G. \& Brothers (RSA\# O 352) (Philosophy).

\#272. Smith, E. G. (1920). Americanism. Chicago: Edward Garstin Smith (RSA\# G 0823) (Social Sciences).

\#273. SPCK. (1920). Conference of the Bishops of the Anglican Communion. London: Society for Promoting Christian Knowledge (SPCK). New York: The Macmillan Company (RSA\# T 158) (Religion). 
\#274. Steiger, I. D. (1916). Super humanity. London: Elliot Stock (RSA\# O 357) (Philosophy).

\#275. Steiner, R. (1908). The Way of Initiation. London: Theosophical Publishing Society (RSA\# St 23) (Theosophy).

\#276. Steiner, R. (1910). Theosophy: An Introduction to the Supersensible Knowledge of the World and the Destination of Man. London: Kegan Paul, Trench \& Trubner \& Co. (RSA\# St 21) (Theosophy).

\#277. Steiner, R. (1914). Christianity as Mystical Fact and the Mysteries of Antiquity. New York - London: G. P. Putnam's Sons (RSA\# St 18; Inscribed to Rudolf Steiner by the editor) (Anthroposophy).

\#278. Steiner, R. (1918). A Road to Self-Knowledge. London - New York: G. P. Putnam's Sons (RSA\# St 49; Inscribed to Rudolf Steiner by the editor) (Anthroposophy).

\#279. Steiner, R. (1918). A Road to Self-Knowledge. London - New York: G. P. Putnam's Sons (RSA\# St 49a; Inscribed to Rudolf Steiner by the editor) (Anthroposophy).

\#280. Steiner, R. (1920). Four Mystery Plays. Volume II: The Guardian of the Threshold, The Soul's Awakening. New York - London: G. P. Putnam's Sons (The Knickerbocker Press) (RSA\# St 45b) (Anthroposophy).

\#281. Steiner, R. (1920). Four Mystery Plays. Volume I: The Portal of Initiation, The Soul's Probation. New York - London: G. P. Putnam's Sons (The Knickerbocker Press) (RSA\# St 45a) (Anthroposophy).

\#282. Steiner, R. (1920). The Threefold State. London: George Allen \& Unwin (RSA\# St 61) (Anthroposophy).

\#283. Steiner, R. (1922). A Road to Self-Knowledge \& The Threshold of the Spiritual World. London - New York: G. P. Putman's Son (RSA\# St 50; Inscribed to Rudolf Steiner by the editor) (Anthroposophy).

\#284. Steiner, R. (1922). An Outline of Occult Science. Chicago: Anthroposophical Literature Concern (RSA\# St 31) (Anthroposophy).

\#285. Steiner, R. (1922). The Philosophy of Spiritual Activity. London - New York: G. P. Putnam's Sons (RSA\# St 11; Inscribed to Rudolf Steiner by Henry Collison, Oxford, 1922) (Anthroposophy).

\#286. Steiner, R. (nd). The Nature and Origin of the Arts. London: Anthroposophical Society (RSA\# St 89) (Anthroposophy).

\#287. Students, T. (1893). Theosophical Gleanings, or Notes on the 'Secret Doctrine'. Madras: Thompson \& Co. (RSA\# 0 545) (Theosophy).

\#288. Subba Row, T. (1897). Lectures on the Study of the Bhagavad-Gita. Bombay: Bombay Theosophical Publication Fund, Tookaram Tatya (RSA\# T 069) (Theosophy).

\#289. Sutcliffe, G. E. (1905). A Gigantic Hoax: How the Great French Astronomer La Place has Perpetrated a Tremendous Hoax on the Whole of Nineteenth Century Scientists. Bombay: Duftur Ashkara Press (RSA\# 0 362) (Theosophy).

\#290. Swiney, F. (1906). The Cosmic Progression. London: Ernest Bell (RSA\# 0 365; Inscribed to Rudolf Steiner by the author) (Science).

\#291. Tagore, R. (1917). My Reminiscences. London: Macmillan and Co (RSA\# G 0876) (History).

\#292. Tate, R. (1872). Rudimentary Treatise on Geology: A Class-book on Geology, Physical and Historical. London: Lockwood \& Co (RSA\# N 541) (Science).

\#293. Theosophical Society. (1901). The Theosophical Society. England: Thomas Green (RSA\# O 648) (Theosophy).

\#294. Theosophical Society. (1906). Transactions of the First Annual Congress of the Federation of European Sections of the Theosophical Society: held in Amsterdam 19-21 June 1904. Amsterdam: The Council of the Federation (RSA\# 0 645) (Theosophy).

\#295. Theosophical Society. (1906). Transactions of the Second Annual Congress of the Federation of European Sections of the Theosophical Society held in London 6-10 July 1906. (Amsterdam: The Council of the Federation (RSA\# 0 646) (Theosophy).

\#296. Thomas, C. (1896). Literature and Personality. New York: Publications of the Modern Language Association of America (RSA\# L 259) (Philosophy).

\#297. Thompson, E. W. (1913). The Theosophy of Mrs. Besant: Being a Statement upon the Teaching of Mrs Besant and Mr Leadbeater. Mysore: Wesleyan Mission Press (RSA\# 0 653) (Theosophy).

\#298. Tingley, K. (c.1896). In Honour of William Q. Judge: Address by Katherine Tingley. Point Loma, CA: The Theosophical Publishing Society (RSA\# O 573) (Theosophy).

\#299. TPS. (1901). Catalogue of New Books and Recent Publications for Sale by the Theosophical Publishing Society. London: The Theosophical Publishing Society (TPS) (RSA\# O 518) (Theosophy).

\#300. TPS. (1901). Catalogue of the Theosophical Lending Library 1901. London: Theosophical Publishing Society (TPS) (RSA\# 0 519) (Theosophy). 
\#301. Trine, R. W. (1907). The Fire of the Heart. London: George Bell \& Sons (RSA\# G 0896) (Social Sciences).

\#302. Tucker, B. R. (1893). Instead of a Book: By a Man too Busy to Write One. New York: Benj. R. Tucker (RSA\# G 0901) (Philosophy).

\#303. V\&A Museum. (1924). List of Illuminated Leaves \& Cuttings in the Travelling Series. London Victoria and Albert Museum: under the Authority of the Board of Education (RSA\# K 115) (Arts).

\#304. Vaswani, T. L. (1922). Atmagnan; or Life in the Spirit. Madras: Ganesh \& Co. (RSA\# O 663; Inscribed to Rudolf Steiner by the author) (Religion).

\#305. Vivekananda, S. (1903). Yoga Philosophy: Lectures delivered in New York, winter of 1895-6, by Swami Vivekananda on Raja Yoga, or Conquering the Internal Nature, also Patanjali's Yoga Aphorisms, with Commentaries. London - New York - Bombay: Longmans, Green \& Co. (RSA\# 0 380) (Philosophy).

\#306. Wallace Collection. (1901). Abridged Catalogue of the Oil Paintings and Water Colours of the Wallace Collection. London: H.M Stationery Office, Hertford House (RSA\# K 113) (Arts).

\#307. Walter, G. O. (trans). (1904). The Shu King; or, the Chinese Historical Classic, Being an Authentic Record of the Religion, Philosophy, Customs and Government of the Chinese from the Earliest Times. London - Benares: The Theosophical Publishing Society (RSA\# 0 628) (Theosophy).

\#308. Webster, N. H. (1921). World Revolution: The Plot Against Civilization. London: Constable \& Company Ltd (RSA\# G 0958) (Social Sciences).

\#309. Westcott, W. W. (trans.). (1893). An English Translation of the Hermetic Arcanum of Penes Nos Unda Tagi. London: Theosophical Publishing Society (RSA\# 0 667) (Theosophy).

\#310. Westcott, W. W. (trans.). (1893). Sepher Yetzirah. The Book of Formation: And the Thirty-two Paths of Wisdom. London: J. M. Watkins (RSA\# 0 676) (Theosophy).

\#311. Westcott, W. W. (1893). The Science of Alchemy, Spiritual and Material. London - New York Adyar/Madras: The Theosophical Publishing Society (RSA\# 0 666) (Theosophy).

\#312. Westcott, W. W. (1894). A Short Enquiry Concerning the Hermetic Art. London - New York: Theosophical Publishing Society (RSA\# 0 669) (Theosophy).

\#313. Westcott, W. W. (1894). Aesch Mezareph or Purifying Fire. London - New York: Theosophical Publishing Society (RSA\# 0 670) (Theosophy).

\#314. Westcott, W. W. (1894). Somnium Scipionis. London - New York: Theosophical Publishing Society (RSA\# 0 671) (Theosophy).

\#315. Westcott, W. W. (1894). The Pymander of Hermes. London - New York: Theosophical Publishing Society (RSA\# 0 668) (Theosophy).

\#316. Westcott, W. W. (1895). The Chaldaen Oracles of Zoroaster. London - Benares - Madras: Theosophical Publishing Society (RSA\# 0 672) (Theosophy).

\#317. Westcott, W. W. (1896). Egyptian Magic. London - New York - Benares - Madras: Theosophical Publishing Society (RSA\# 0 674) (Theosophy).

\#318. Westcott, W. W. (1896). Euphrates or the Waters of the East. London - Benares - Madras: Theosophical Publishing Society (RSA\# 0 673) (Theosophy).

\#319. Westcott, W. W. (1902). Numbers, their Occult Power and Mystic Virtues. London - Benares: Theosophical Publishing Society (RSA\# 0 675) (Theosophy).

\#320. Westcott, W. W. (1911). Sepher Yetzirah. The Book of Formation: With the Fifty Gates of Intelligence and the Thirty-two Paths of Wisdom. London: J. M. Watkins (RSA\# 0 677) (Theosophy).

\#321. Westcott, W. W. (1916). Data of the History of the Rosicrucians. London: J. M. Watkins (RSA\# 0 321) (History).

\#322. Wilkinson, J. G. (1854). A Popular Account of the Ancient Egyptians: in Two Volumes. Volume II. London: John Murray (RSA\# G 0978) (History).

\#323. Willson, T., E. (1902). Ancient and Modern Physics. New York: Charles Johnston (RSA\# N 594) (Science).

\#324. Willy, R. (1908). An Occultist's Travels. New York: R. F. Fenno \& Company (RSA\# O 311) (Religion).

\#325. Windle, B. C. A. (c.1904). The Catholic Aspect of the Education Question. London: Catholic Truth Society (RSA\# T 685) (Religion).

\#326. Wright, D. (1908). Was Jesus an Essene? Wimbledon: Power Book Co. (RSA\# T 689) (Religion).

\#327. Wright, D. D. A. (1909). The Evolution of the Human Consciousness: Its Past and its Future. London: np (RSA\# P 200a) (Philosophy). 